\title{
Estimating the global abundance of ground level presence of particulate matter $\left(\mathbf{P M}_{2.5}\right)$
}

\author{
David J. Lary ${ }^{1}$, Fazlay S. Faruque ${ }^{2}$, Nabin Malakar ${ }^{1}$, Alex Moore ${ }^{1}$, Bryan Roscoe ${ }^{1}$, \\ Zachary L. Adams ${ }^{1}$, York Eggelston ${ }^{3}$ \\ ${ }^{1}$ Hanson Center for Space Science, University of Texas at Dallas, Dallas, USA; ${ }^{2}$ GIS and Remote Sensing \\ Program, University of Mississippi Medical Center, Jackson, USA; ${ }^{3}$ Machine Data Learning Llc, Baltimore, USA
}

\begin{abstract}
With the increasing awareness of the health impacts of particulate matter, there is a growing need to comprehend the spatial and temporal variations of the global abundance of ground level airborne particulate matter with a diameter of 2.5 microns or less $\left(\mathrm{PM}_{2.5}\right)$. Here we use a suite of remote sensing and meteorological data products together with groundbased observations of particulate matter from 8,329 measurement sites in 55 countries taken 1997-2014 to train a machinelearning algorithm to estimate the daily distributions of $\mathrm{PM}_{2.5}$ from 1997 to the present. In this first paper of a series, we present the methodology and global average results from this period and demonstrate that the new $\mathrm{PM}_{2.5}$ data product can reliably represent global observations of $\mathrm{PM}_{2.5}$ for epidemiological studies.
\end{abstract}

Keywords: $\mathrm{PM}_{2.5}$, machine-learning, remote sensing.

\section{Introduction}

Numerous studies show that among air pollutants, particulate matter (PM), especially with a diameter of 2.5 microns or less $\left(\mathrm{PM}_{2.5}\right)$, has the strongest link with human health effects (Brook et al., 2010a,b, 2013a,b; Pope et al., 2011; Lary et al., 2014). Increased morbidity and mortality has been associated with exposure to $\mathrm{PM}_{2.5}$ suggesting that improved life expectancy is possible by reducing the exposure level (Pope et al., 2009). Not only in the United States of America (USA), but also in European studies, a significant number of premature deaths, including those due to cardiopulmonary and lung cancer, are attributed to long-term exposure to $\mathrm{PM}_{2.5}$ (Boldo et al., 2006, 2011; Ballester et al., 2008). The many health impacts of such particulate matter (Table 1 ) depend in part on its abundance at ground level in the atmospheric boundary layer where it can be inhaled.

For more than half a century, researchers have been studying the impact of PM on health. Initially the attempt was to learn about the possible adverse effects; then the focus shifted to investigate the exposure-response relationships. With further advancement in technology and more awareness of health-concerns,

\section{Corresponding author:}

David Lary

Hanson Center for Space Science

University of Texas at Dallas, Dallas, USA

Tel. +1 972 489-2059; Fax +1 972 883-2761

E-mail: david.lary@utdallas.edu studies on composition-specific effects have emerged (Ayala et al., 2012). With implementation of computational fluid dynamics (CFD) models and digital imaging of organs, researchers have started to study the pathophysiology associated with PM to better understand the translocation of particulates in the human body after their deposition and how they impact health.

Most short-term exposure impact studies on $\mathrm{PM}_{2.5}$, whether for morbidity or mortality, focus on cardiovascular/cardiopulmonary (Brook et al., 2010b) or respiratory (Dockery et al., 1993) conditions. Our dataset, with daily temporal scale, is suitable for such studies. We are already studying daily asthma-related hospital admissions associated with $\mathrm{PM}_{2.5}$ using our estimated data. On the other hand, diseases, such as lung cancer, require study of long-term exposure. Data generated from this study are expected to contribute to Health Impact Assessment (HIA) in different parts of the world concerning long-term exposure to $\mathrm{PM}_{2.5}$. Currently, long-term values are not available in many localities and in many instances, $\mathrm{PM}_{2.5}$ values are estimated from $\mathrm{PM}_{10}$ for long-term HIA (Boldo et al., 2011). Studies also suggest that even low-level $\mathrm{PM}_{2.5}$ exposure can contribute to serious health impacts (Pope et al., 2006; Franklin et al., 2007; Crouse et al., 2012; Cesaroni et al., 2014). We have already created daily global estimates of $\mathrm{PM}_{2.5}$ with an associated uncertainty for more than 13 years providing an appropriate dataset for extended cohort studies for the areas with both high and mid-level concentrations of ambient $\mathrm{PM}_{2.5}$. In addition, long-range trans- 
Table 1. Particulate matter and health outcomes for $\mathrm{PM}_{10}, \mathrm{PM}_{2.5}$ and ultrafine particles (UFPs).

\begin{tabular}{|c|c|c|c|c|c|c|}
\hline \multirow{2}{*}{ Health outcomes } & \multicolumn{3}{|c|}{ Short-term studies } & \multicolumn{3}{|c|}{ Long-term studies } \\
\hline & $\mathrm{PM}_{10}$ & $\mathrm{PM}_{2.5}$ & UFP & $\mathrm{PM}_{10}$ & $\mathrm{PM}_{2.5}$ & UFP \\
\hline \multicolumn{7}{|l|}{ Mortality } \\
\hline All causes & $\mathrm{xxx}$ & $\mathrm{xxx}$ & $\mathrm{x}$ & $\mathrm{xx}$ & $\mathrm{xx}$ & $\mathrm{x}$ \\
\hline Cardiovascular & $\mathrm{xxx}$ & $\mathrm{xxx}$ & $\mathrm{x}$ & $\mathrm{xx}$ & $\mathrm{xx}$ & $\mathrm{x}$ \\
\hline Pulmonary & $\mathrm{xxx}$ & $\mathrm{xxx}$ & $\mathrm{x}$ & $\mathrm{xx}$ & $\mathrm{xx}$ & $\mathrm{x}$ \\
\hline \multicolumn{7}{|l|}{ Pulmonary effect } \\
\hline Lung function, e.g. PEF & $\mathrm{xxx}$ & $\mathrm{xxx}$ & $\mathrm{xx}$ & $\mathrm{xxx}$ & $\mathrm{xxx}$ & \\
\hline Lung function growth & & & & $\mathrm{xxx}$ & $\mathrm{xxx}$ & \\
\hline \multicolumn{7}{|l|}{ Asthma and COPD exacerbation } \\
\hline Acute respiratory symptoms & & $\mathrm{xx}$ & $\mathrm{x}$ & $\mathrm{xxx}$ & $\mathrm{xxx}$ & \\
\hline Medication use & & & $\mathrm{x}$ & & & \\
\hline Hospital admission & $\mathrm{xx}$ & $\mathrm{xxx}$ & $\mathrm{x}$ & & & \\
\hline \multicolumn{7}{|l|}{ Lung cancer } \\
\hline Cohort & & & & $\mathrm{xx}$ & $\mathrm{xx}$ & $\mathrm{x}$ \\
\hline Hospital admission & & & & $\mathrm{xx}$ & $\mathrm{xx}$ & $\mathrm{x}$ \\
\hline \multicolumn{7}{|l|}{ Cardiovascular effects } \\
\hline Hospital admission & $\mathrm{xxx}$ & $\mathrm{xxx}$ & & $\mathrm{x}$ & $\mathrm{x}$ & \\
\hline \multicolumn{7}{|l|}{ ECG-related endpoints } \\
\hline Autonomic nervous system & $\mathrm{xxx}$ & $\mathrm{xxx}$ & $\mathrm{xx}$ & & & \\
\hline Myocardial substrate and vulnerability & & $\mathrm{xx}$ & $\mathrm{x}$ & & & \\
\hline \multicolumn{7}{|l|}{ Vascular function } \\
\hline Blood pressure & $\mathrm{xx}$ & $\mathrm{xxx}$ & $\mathrm{x}$ & & & \\
\hline Endothelial function & $\mathrm{x}$ & $\mathrm{xx}$ & $\mathrm{x}$ & & & \\
\hline \multicolumn{7}{|l|}{ Blood markers } \\
\hline Pro inflammatory mediators & $\mathrm{xx}$ & $\mathrm{xx}$ & $\mathrm{xx}$ & & & \\
\hline Coagulation blood markers & $\mathrm{xx}$ & $\mathrm{xx}$ & $\mathrm{xx}$ & & & \\
\hline Diabetes & $\mathrm{x}$ & $\mathrm{xx}$ & $\mathrm{x}$ & & & \\
\hline Endothelial function & $\mathrm{x}$ & $\mathrm{x}$ & $\mathrm{xx}$ & & & \\
\hline \multicolumn{7}{|l|}{ Reproduction } \\
\hline Premature birth & $\mathrm{x}$ & $\mathrm{x}$ & & & & \\
\hline Birth weight & $\mathrm{xx}$ & $\mathrm{x}$ & & & & \\
\hline IUR/SGA & $\mathrm{x}$ & $\mathrm{x}$ & & & & \\
\hline \multicolumn{7}{|l|}{ Fetal growth } \\
\hline Birth defects & $\mathrm{x}$ & & & & & \\
\hline Infant mortality & $\mathrm{xx}$ & $\mathrm{x}$ & & & & \\
\hline Sperm quality & $\mathrm{x}$ & $\mathrm{x}$ & & & & \\
\hline \multicolumn{7}{|l|}{ Neurotoxic effects } \\
\hline Central nervouse system & & $\mathrm{x}$ & $\mathrm{xx}$ & & & \\
\hline
\end{tabular}

$\mathrm{x}=$ few studies $(6$ or less); $\mathrm{xx}=$ many studies $(7-10) ; \mathrm{xxx}=$ large number of studies $(>10)$.

portation of particles as, such dust can provide potential vectors for bacteria (Ginoux and Torres, 2003; Prospero, 2003). With global coverage of this study, tracking $\mathrm{PM}_{2.5}$ transport is now easier for public health surveillance.

In recent years, researchers are finding it worthy to investigate potential links between $\mathrm{PM}_{2.5}$ exposure and adverse birth outcomes (Slama et al., 2008; Dadvand et al., 2013), epigenetic alteration (Baccarelli et al., 2008; Salam et al., 2012; Byun et al., 2013; Hou et al., 2013) infant mortality (Woodruff et al., 1997; Lipfert et al., 2000; Dales et al., 2004; Glinianaia et al., 2004) atherosclerosis (Araujo et al., 2008; Araujo, 2011; Kaufman, 2011), stroke (Brook, 2008; Brook and Rajagopalan, 2009, 2012; Maheswaran et al., 2010, 2012), rheumatic autoimmune disease (Zeft et al., 
2009; Farhat et al., 2011), central nervous system disorders (Sunderman, 2001; Kreyling et al., 2006; Block and Calderon-Garciduenas, 2009; Pearson et al., 2010; Wang et al., 2012) and diabetes (Andersen, 2012; Andersen et al., 2012). Since many of these health conditions are interlinked, comprehensive studies are required to better understand the impact of $\mathrm{PM}_{2.5}$. With increasing availability of electronic health records, reliable $\mathrm{PM}_{2.5}$ data with seamless temporal and geographic coverage can contribute to revealing many unknowns of $\mathrm{PM}_{2.5}$ impacts on health.

It could be noted that the type and degree of adverse effect greatly depends on the composition of the particulate matters. Composition mostly varies due to source materials. Our current study does not provide information on the composition of $\mathrm{PM}_{2.5}$. However, this study can be extended to examine the potential of source apportionment considering land use / land cover conditions and transportation mechanisms. Recent studies show specific adverse impacts of exposure to ultrafine particles (UFPs). Future studies are recommended to derive further size fractions beyond just $\mathrm{PM}_{2.5}$, particularly UFPs in the sub-micron size range. Various networks of ground-based sensors routinely measure the abundance of $\mathrm{PM}_{2.5}$. However, the spatial coverage has many large gaps and in some countries no observations are made at all. Globally more observations of $\mathrm{PM}_{10}$ are available than for $\mathrm{PM}_{2.5}$. This paper focuses on $\mathrm{PM}_{2.5}$, which has been related to a wider variety of health conditions than $\mathrm{PM}_{10}$ or UFPs (Table 1).

Several studies have sought to overcome this limitation of spatial coverage by using remote sensing and satellite-derived Aerosol Optical Depth (AOD) coupled with regression and/or numerical models to estimate the ground-level abundance of $\mathrm{PM}_{2.5}$ (e.g. EngelCox et al., 2004a; Zhang et al., 2009, 2011; Hoff and Christopher, 2009; Weber et al., 2010). Studies have shown that the relationship between $\mathrm{PM}_{2.5}$ and AOD is not always suitable for simple regression models. Rather it is determined by a multi-variate function of a large number of parameters, including: humidity, temperature, boundary layer height, surface pressure, population density, topography, wind speed, surface type, surface reflectivity, season, land use, normalised variance of rainfall events, size spectrum and phase of cloud particles, cloud cover, cloud optical depth, cloud top pressure and the proximity to particulate sources releasing $\mathrm{PM}_{2.5}$ (Liu et al., 2005; Lyamani et al., 2006; Choi et al., 2008; Paciorek et al., 2012; Zhang et al., 2009). The picture is further complicated by the biases present in satellite AOD products (e.g.
Lary et al., 2009; Hyer et al., 2011; Shi et al., 2012; Reid et al., 2013), the difference in spatial scales of the in-situ point $\mathrm{PM}_{2.5}$ observations and remote sensing data (several $\mathrm{km}$ per pixel) and, finally, the sharp $\mathrm{PM}_{2.5}$ gradients that can exist in and around cities.

Zhang et al. (2009) presented a comprehensive study for the ten Environmental Protection Agency (EPA) regions across USA using multi-linear regression between the $\mathrm{PM}_{2.5}$ abundance observed by the EPA monitoring sites and the Moderate Resolution Imaging Spectroradiometer (MODIS), AOD and a set of meteorological parameters. In their multi-linear regression study (Zhang et al., 2009) found the best correlations of $\mathrm{PM}_{2.5}$ with AOD in the eastern states during summer and autumn, with EPA region number 4 having a correlation coefficient of more than 0.6. They observed the poorest correlation for the southwestern USA, with EPA region number 9 having a correlation coefficient of approximately 0.2. Weber et al. (2010) extended the work by Zhang et al. (2009) for five EPA monitoring sites in the Baltimore/Washington DC Metro area by considering AOD from MODIS, the Multi-Angle Imaging Spectroradiometer (MISR) and the Geostationary Operational Environmental Satellite (GOES). These $\mathrm{PM}_{2.5}$ estimates are made available through the Infusing satellite Data into Environmental Applications (IDEA) website (http://www.star.nesdis. noaa.gov/smcd/spb/aq/).

In a notable study, van Donkelaar et al. (2006) took the alternative approach of using remote sensing and a global transport model to present a global estimate of the long-term average $\mathrm{PM}_{2.5}$ concentrations between the years 2001 and 2006 using satellite observations of AOD from MODIS to estimate $\eta=\mathrm{PM}_{2.5} / \mathrm{AOD}$. The three-dimensional (3D) chemical transport model used was GEOS-Chem (http://acmg.seas.harvard.edu/geos/), and the authors found a significant spatial agreement with their estimates; the correlation coefficient for North American $\mathrm{PM}_{2.5}$ measurements was 0.77 and elsewhere 0.83. $\mathrm{PM}_{2.5}$ estimates using this approach have since been used in a variety of health studies (van Donkelaar et al., 2010a; Anderson et al., 2012; Brauer et al., 2012; Crouse et al., 2012; Hystad et al., 2012). Meanwhile, Liu et al. estimated the ground level abundance of $\mathrm{PM}_{2.5}$ by using scaling factors from the GEOS-Chem, GOCART models and AOD from the MISR (Liu et al., 2004, 2005, 2007a,b,c, 2009a,b,c).

This study makes five incremental contributions:

(i) we believe we have used the most comprehensive training dataset to date for a study that empirically relates hourly in situ $\mathrm{PM}_{2.5}$ observa- 
tions to remote sensing, meteorological and other contextual, environmental data. This is important as the local context of the various $\mathrm{PM}_{2.5}$ observations varies widely and in order to have a robust estimation of the global $\mathrm{PM}_{2.5}$ distribution, we need representative observations in a wide range of conditions. Hourly $\mathrm{PM}_{2.5}$ observations were acquired from 1997-present from across the world. In this study we used hourly $\mathrm{PM}_{2.5}$ data from 8,329 measurement sites in 55 countries;

(ii) we believe we have used the widest range of contextual variables to date (over 30 identified from the literature and presented in the last section) in our analysis of the measured multivariate, nonlinear, non-parametric relationship between ground based observations of $\mathrm{PM}_{2.5}$ and remote sensing observations, meteorological observations and associated contextual information;

(iii) we have used the most-suitable multivariate, nonlinear, non-parametric machine-learning approach currently available (briefly described in the next section) and not previously used for investigating the empirical relationship between hourly in-situ $\mathrm{PM}_{2.5}$ observations and remote sensing, meteorological and other contextual environmental data;

(iv) we not only estimate the $\mathrm{PM}_{2.5}$ abundance, but also provide an uncertainty estimate; and

(v) we cover the longest time period estimating the $\mathrm{PM}_{2.5}$ abundance on a daily basis (from September 1, 1997 to the present).

\section{Materials and methods}

Many studies have shown that the relationship between $\mathrm{PM}_{2.5}$ and AOD is a multi-variate function of a large number of parameters (Liu et al., 2005; Lyamani et al., 2006; Choi et al., 2008; Natunen et al., 2010; Liu and Harrison, 2011). Further, many of these relationships are non-linear, some are of unknown functional form and many have non-Gaussian distributions. Therefore, any successful description of the relationship between $\mathrm{PM}_{25}$ and $\mathrm{AOD}$ needs to be multi-variate, non-parametric (we do not know the functional form from theory) and able to deal with non-linear behaviour and non-Gaussian distributed variables. This would suggest that a machine-learning algorithm should be used.

Machine-learning can provide a valuable regression tool for empirically estimating variables of interest, when we do not have a complete theoretical descrip- tion of a process but do have a useful set of observations. Machine-learning encompasses a broad range of algorithms (e.g. Neural Networks, Support Vector Machines, Gaussian Processes, Decision Trees, Random Forests, etc.) that can provide multi-variate, non-linear, non-parametric regression or classification based on a training dataset. We have used all of these approaches for estimating $\mathrm{PM}_{2.5}$ and have also developed our own proprietary ensemble approach with full error estimation (a description of which is beyond the scope of this text). The key points to highlight as relevant to this study are:

(i) the approach includes a full independent validation. A fraction of the training data is randomly selected and held back for independent validation. These validation points are shown in red in Fig. 3;

(ii) at every location we considered, the approach provides both an estimate of the $\mathrm{PM}_{2.5}$ abundance as well as an error estimate;

(iii) an ensemble of independent predictors are used at every location, and our estimate of the $\mathrm{PM}_{2.5}$ abundance is the mean of the ensemble of estimates. A full error characterisation showed that beyond an ensemble size of 6 , there was no significant error reduction. However, we used an ensemble size of 12 to be completely sure we had an ensemble that was large enough;

(iv) the approach provides a ranking of the relative importance of each of the variables used in the regression;

(v) the approach can handle records with missing values. However, in this study we chose to ignore records with missing values.

\section{Datasets used in machine-learning regression}

$P M_{2.5}$ data - We used as many in-situ hourly $\mathrm{PM}_{2.5}$ observations as possible from 8,329 sites in 55 countries from August 1, 1997 to the present (shown as red squares in Fig. 1). Fig. 2 shows the spatial and temporal coverage of this training data. Most of the observation sites were in the northern hemisphere. The highlatitude satellite data coverage is greatest in summer, so the number of in-situ $\mathrm{PM}_{2.5}$ observations with satellite overpasses is greatest in summer as can be seen by the annual summer peaks in the Figure. Having training data from as many different physical environments as possible is critical, so a wide range of diverse conditions should be incorporated in the training data. The quality of the global machine-learning estimates of $\mathrm{PM}_{2.5}$ improved dramatically with the inclusion of 


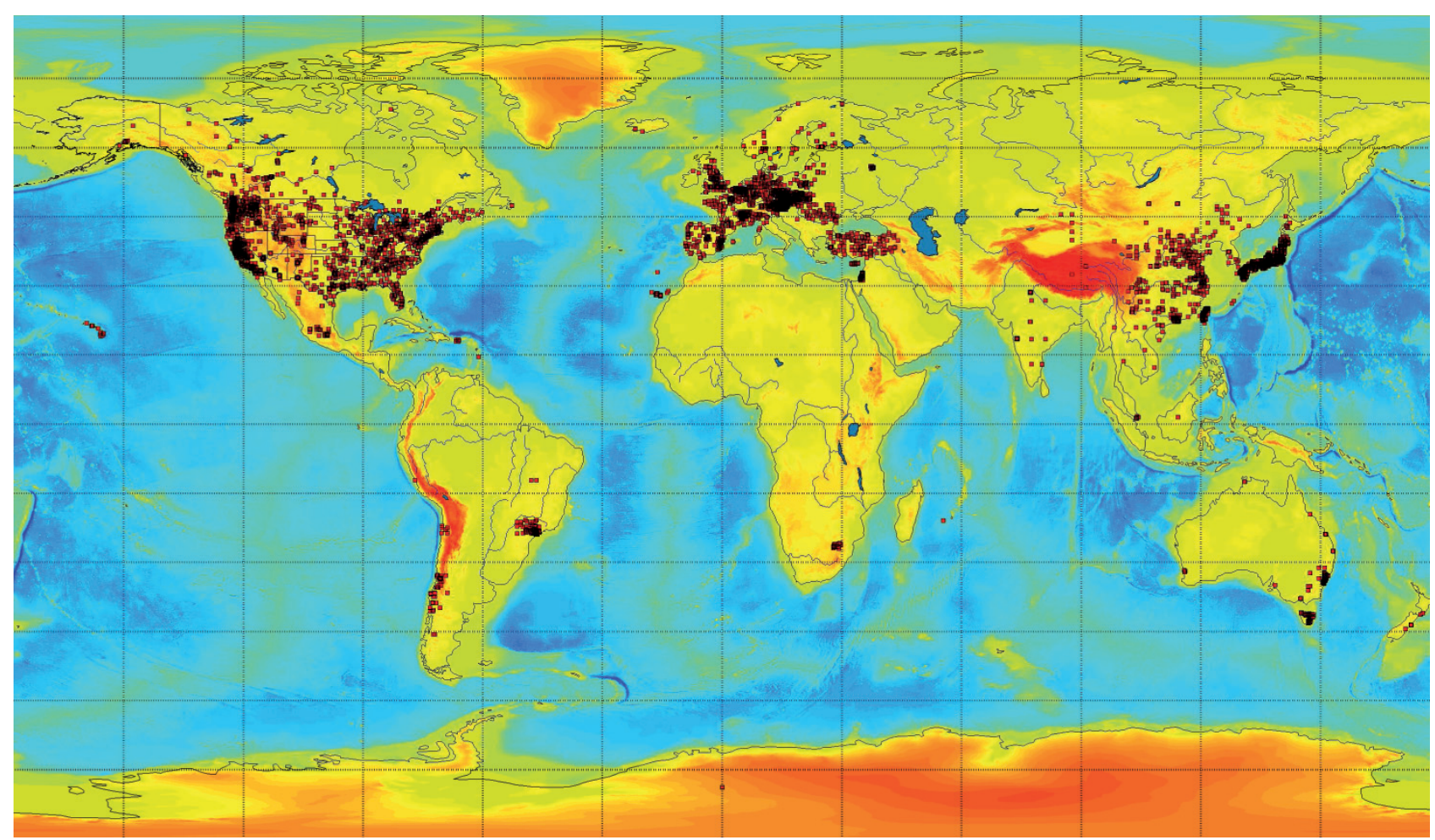

Fig. 1. Map showing the 8,329 $\mathrm{PM}_{2.5}$ measurement site locations from 55 countries studied 1997-2014. Black squares show sites, where measurements were made against the background colour scale of global topography and bathymetry. North America, Europe and Asia have the greatest density of sites but there are also southern hemisphere sites in South America, South Africa, Australia and New Zealand.

data from the southern hemisphere (Chile, Brazil, South Africa, Australia and New Zealand) and Asia (China, India, Japan, Taiwan and Hong Kong). A random sample comprising $5 \%$ of each training dataset was held back for independent evaluation of the $\mathrm{PM}_{2.5}$ estimate produced using machine-learning.

Satellite AOD data - This study used satellite data from three satellite instruments: the Sea-viewing Wide Field-of-view Sensor (SeaWIFS) launched on August 1, 1997 (Melin et al., 2013). Two MODIS instruments (one onboard the Terra satellite (EOS AM) launched in 1999, the other on Aqua (EOS PM) launched in 2002) (Remer et al., 2008) were chosen, both for their coverage and their near-real time data delivery. The latest distribution of MODIS data collection 5.1 was used. In this study we used the level 2 collection 5.1 data and a spatial grid with a resolution of $10 \times 10 \mathrm{~km}$ (approximately $0.1^{\circ} \times 0.1^{\circ}$ ). MODIS collection 5 introduced the Deep Blue algorithm for retrieval of AOD over bright arid surfaces, an approach based on the idea that desert regions are darker at shorter wavelengths so the aerosol signal is clearer when using the shorter deep blue wavelengths (Hsu et al., 2004, 2006; Sayer et al., 2013).

The MODIS aerosol data files are called MOD04 for Aqua and MYD04 for Terra. In addition to the MODIS aerosol optical depth over land and ocean, the product data files include the viewing and solar illumination geometries, surface reflectance, scattering angle, angstrom exponent and various quality and cloud flags. These additional parameters turned out to be invaluable in providing an accurate multivariate, non-parametric regression to estimate the surface abundance of $\mathrm{PM}_{2.5}$.

In MODIS collection 5.1, Deep Blue Terra data are not available after 2007. When collection 6 is released this should be remedied, there will be greater Deep Blue data coverage and higher spatial resolution. Collection 6 will include various refinements to Deep Blue, including extended coverage to vegetated and bright land surfaces, improved cloud screening and surface reflectance and aerosol microphysical models. Many of these improvements were developed during the recent application of Deep Blue to SeaWiFS data.

Meteorological data - The meteorological data used in this study come from the NASA Modern Era Retrospective analysis for Research and Applications (MERRA) (http://gmao.gsfc.nasa.gov/merra/) (Rienecker et al., 2011). The historic data are available from the Modeling and Assimilation Data and 

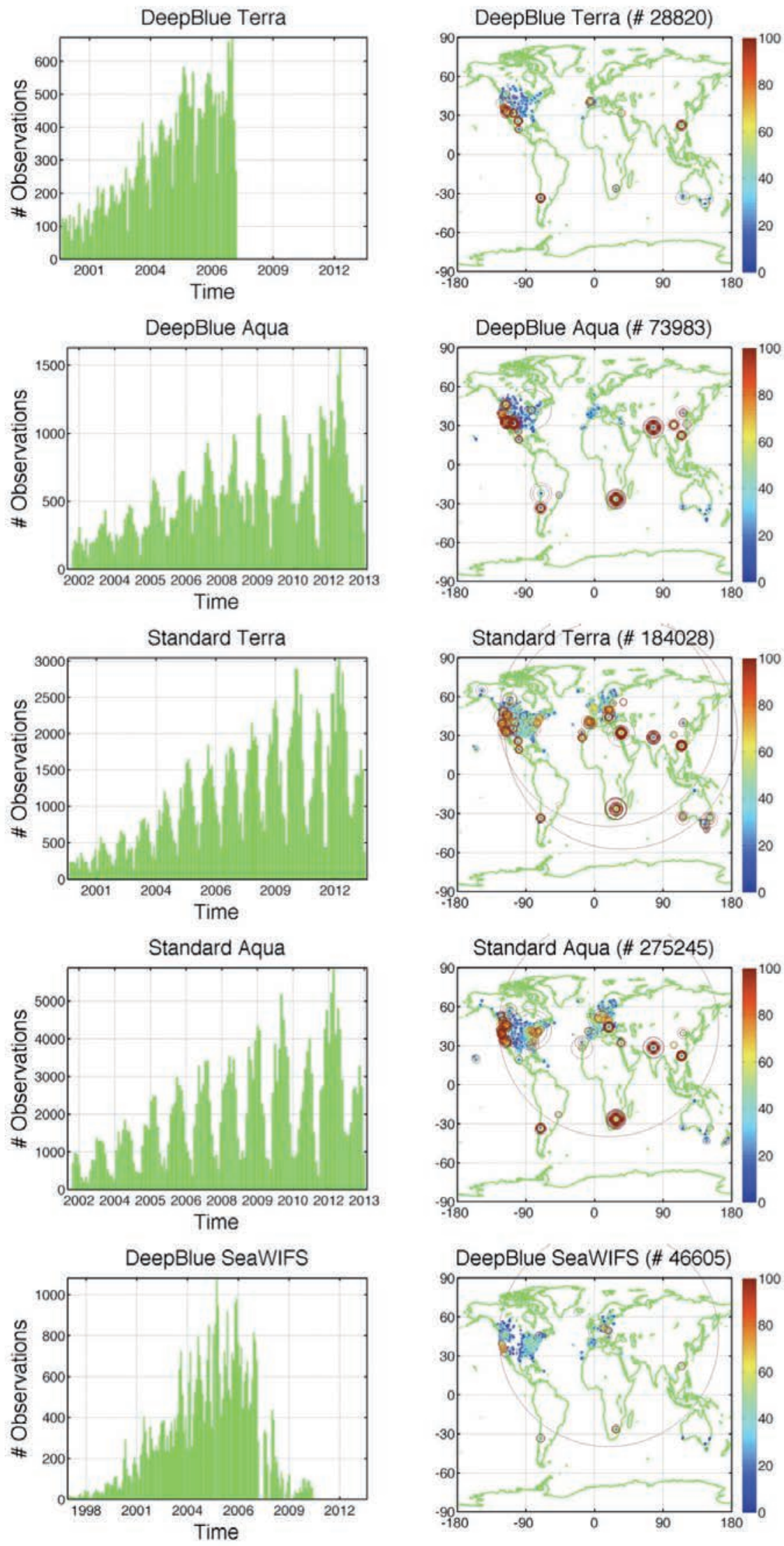

Fig. 2. Temporal (left) and spatial distribution (right) of the training data. The temporal range is different for each instrument and algorithm combination. The size of the symbols in the panels to the right is proportional to the $\mathrm{PM}_{2.5}$ abundance. 
Information Services Center (MDISC) at http://disc.sci.gsfc.nasa.gov/mdisc/. The real-time and forecast data are available as part of the experimental forecast suite at http:/gmao.gsfc.nasa.gov/forecasts/.

\section{$P M_{2.5}$ product evaluation}

Let us now evaluate the quality of the machinelearning regression using several different approaches. Scatter diagrams - Scatter diagrams using data for the entire period of 1997 to present provide a visual means for evaluating the quality of the estimated $\mathrm{PM}_{2.5}$ abundance. A perfect fit would yield a scatter diagram with a slope of one and an intercept of zero. Fig. 3 shows scatter diagrams of the observed in-situ hourly average $\mathrm{PM}_{2.5}$ abundance in $\mu \mathrm{g} / \mathrm{m}^{3}$ on the $\mathrm{x}$-axis and the machine-learning estimate on the $y$-axis. The blue circles depict the training dataset and the red squares the randomly chosen independent validation dataset; the associated probability density function is shown
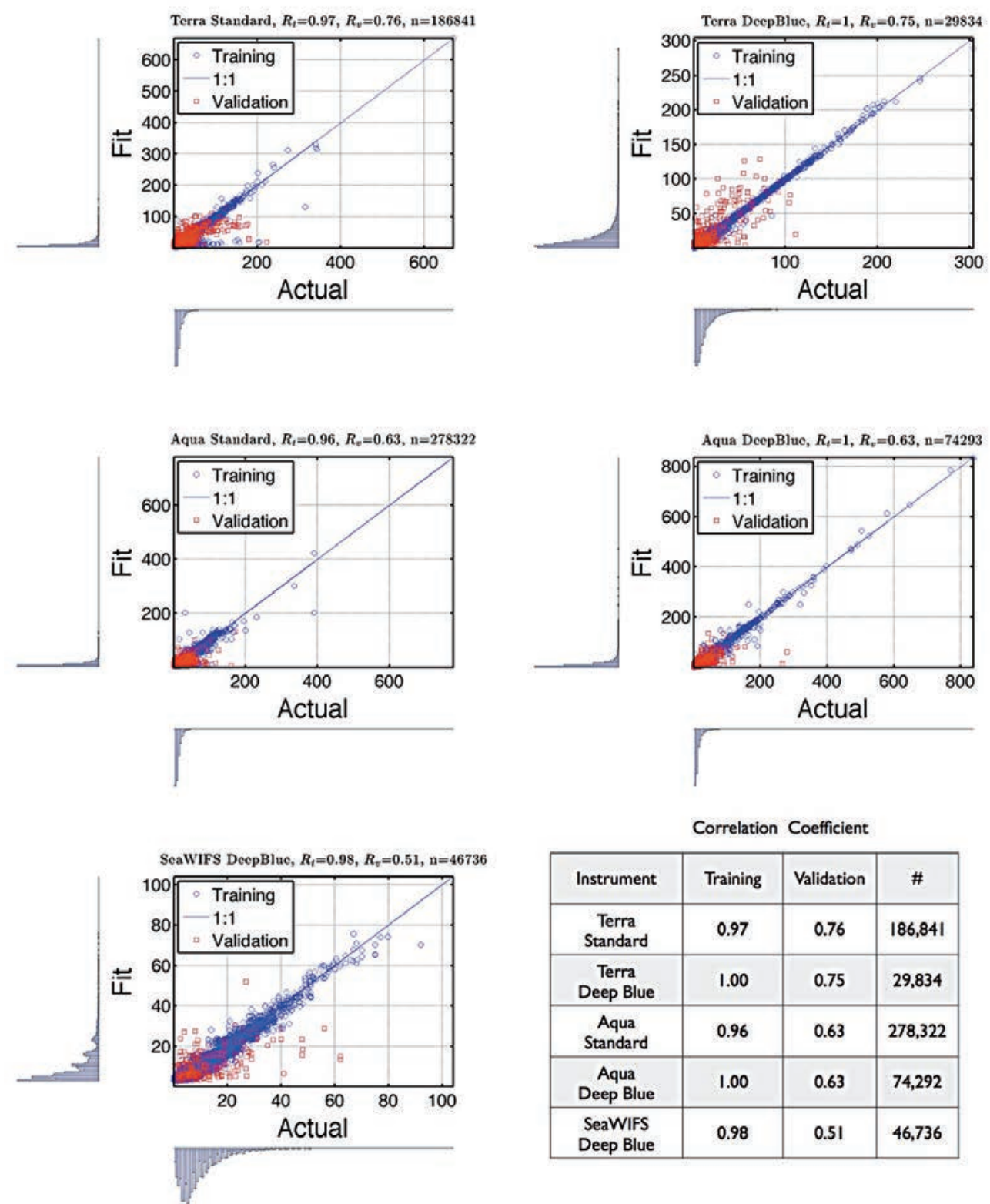

\begin{tabular}{|c|c|c|c|}
\hline & Correlation & Coefficient & \\
\hline Instrument & Training & Validation & \# \\
\hline $\begin{array}{c}\text { Terra } \\
\text { Standard }\end{array}$ & 0.97 & 0.76 & $|86,84|$ \\
\hline $\begin{array}{c}\text { Terra } \\
\text { Deep Blue }\end{array}$ & 1.00 & 0.75 & 29,834 \\
\hline $\begin{array}{c}\text { Aqua } \\
\text { Standard }\end{array}$ & 0.96 & 0.63 & 278,322 \\
\hline $\begin{array}{c}\text { Aqua } \\
\text { Deep Blue }\end{array}$ & 1.00 & 0.63 & 74,292 \\
\hline $\begin{array}{l}\text { SeaWIFS } \\
\text { Deep Blue }\end{array}$ & 0.98 & 0.51 & 46,736 \\
\hline
\end{tabular}

Fig. 3. Scatter diagrams showing the hourly average $\mathrm{PM}_{2.5}$ abundance. $\mathrm{PM}_{2.5}$ load in $\mu \mathrm{g} / \mathrm{m}^{3}$ on the $\mathrm{x}$-axis and the machine-learning estimate (or fit) on the y-axis. The associated probability density function is also shown along each axis. The title of each plot shows the MODIS product used, the correlation coefficient for the training dataset $\left(R_{t}\right)$, the correlation coefficient for the independent validation dataset (the $5 \%$ random selection of data left out of the training data set for independent validation - $R_{\nu}$ and the sample size $(n))$. The blue circles represent the data used in the training and the red squares the independent validation dataset. The table insert gives the correlation coefficients in descending order of the correlation coefficient for the independent validation dataset. 
along each axis. The title of each panel shows the satellite data product used, the correlation coefficient for the independent training dataset $\mathrm{R}_{t}$, the correlation coefficient for the independent validation dataset $\mathrm{R}_{v}$ and the sample size $n$. The table tabulates the correlation coefficients in descending order of $\mathrm{R}_{v}$. It should be noted that the correlation coefficient for each of the five training datasets is 0.96 or greater and that the estimates (blue circles) are tightly clustered about the 1:1 line. The correlation coefficient for each of the independent validation datasets (red squares) is 0.52 or greater and, as would be expected, there is a little more scatter. We see that the quality varies slightly by satellite with the best fits obtained from Terra data, followed by Aqua and then SeaWIFS.
Quintile-Quintile plots - these permit comparison between the shapes of the observed and the estimated probability density functions. Two probability density functions of the same shape yield a straight line. For a good agreement we expect at least the $25^{\text {th }}$ to $75^{\text {th }}$ quintiles (the "overplotted" red squares) to form a straight line as it does for our machine-learning fits of the $\mathrm{PM}_{2.5}$ abundance.

The probability density functions (PDF) are shown along each axis of the scatter diagrams in Fig. 3. We can see that the PDFs of the in-situ observations and our machine-learning estimates have very similar shapes. The relative shapes of the independent validation PDFs are further tested graphically using quintilequintile plots (Fig. 4). The observed $\mathrm{PM}_{2.5}$ abundance
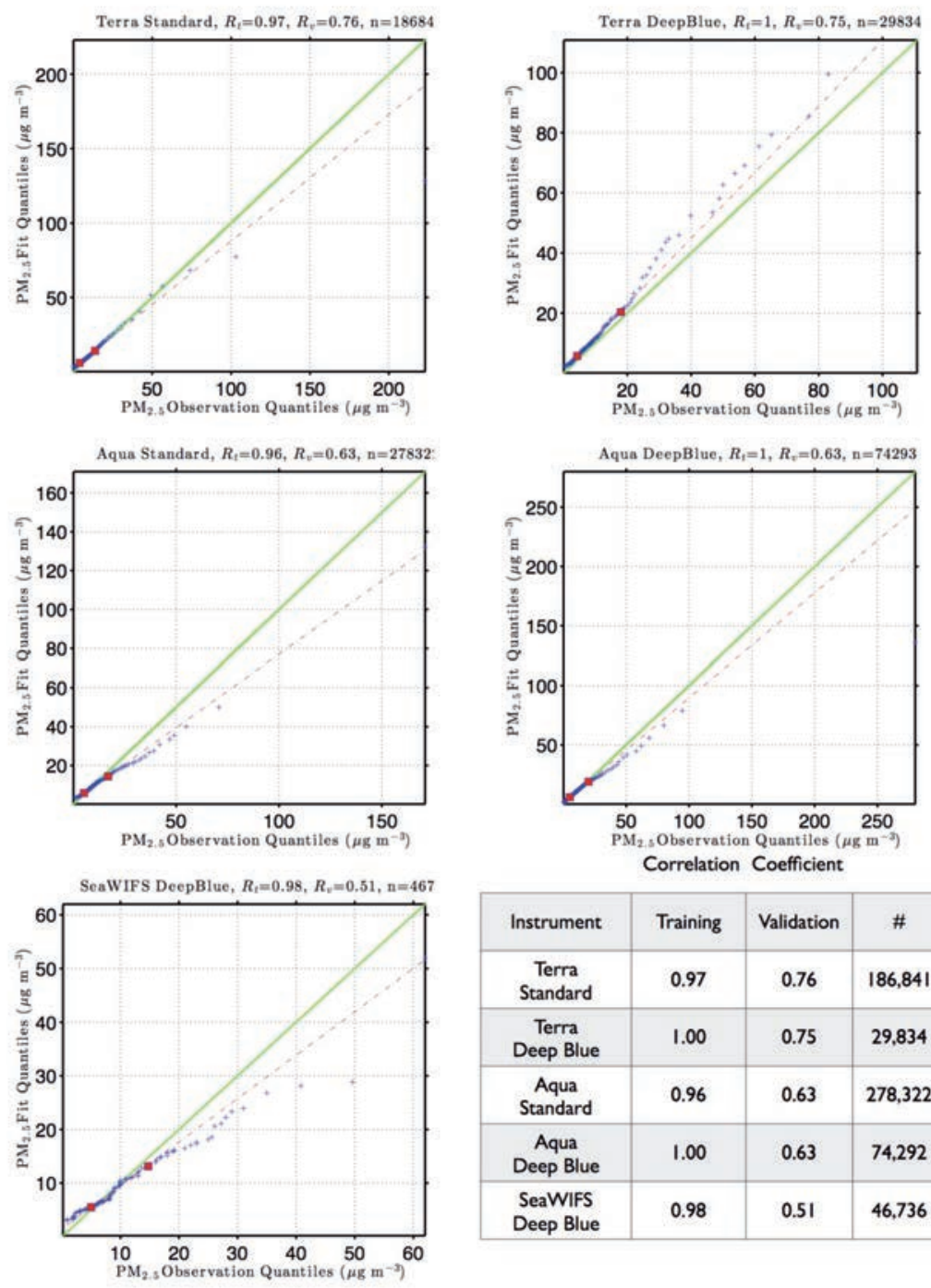

\begin{tabular}{|c|c|c|c|}
\hline Instrument & Training & Validation & $\#$ \\
\hline $\begin{array}{c}\text { Terra } \\
\text { Standard }\end{array}$ & 0.97 & 0.76 & 186,841 \\
\hline $\begin{array}{c}\text { Terra } \\
\text { Deep Blue }\end{array}$ & 1.00 & 0.75 & 29,834 \\
\hline $\begin{array}{c}\text { Aqua } \\
\text { Standard }\end{array}$ & 0.96 & 0.63 & 278,322 \\
\hline $\begin{array}{c}\text { Aqua } \\
\text { Deep Blue }\end{array}$ & 1.00 & 0.63 & 74,292 \\
\hline $\begin{array}{c}\text { SeaWIFS } \\
\text { Deep Blue }\end{array}$ & 0.98 & 0.51 & 46,736 \\
\hline
\end{tabular}

Fig. 4. Quintile-quintile diagrams for the independent validation data showing the observed quintiles of in-situ hourly average $\mathrm{PM}_{2.5}$ abundance. $\mathrm{PM}_{2.5}$ abundance in $\mu \mathrm{g} / \mathrm{m}^{3}$ on the $\mathrm{x}$-axis and the machine-learning estimated quintiles on the $\mathrm{y}$-axis. The blue circles represent the data used in the training and the red squares the independent validation dataset. The table insert gives the correlation coefficients in descending order for the independent validation dataset. Every percentile between 1 and 100 plotted. 
quintiles are plotted on the $\mathrm{x}$-axis and the machinelearning estimated $\mathrm{PM}_{2.5}$ abundance quintiles for the independent validation dataset on the y-axis. Typically the $25^{\text {th }}$ to $75^{\text {th }}$ quintiles of globally observed $\mathrm{PM}_{2.5}$ abundance falls in the range of $5-20 \mu \mathrm{g} / \mathrm{m}^{3}$. The extremely polluted areas in Asia and around some large cities are outliers (falling above the $75^{\text {th }}$ quintile) in the global $\mathrm{PM}_{2.5}$ abundance PDF.

If the quintile-quintile plot is a straight line $\mathrm{y}=\mathrm{ax}+$ $\mathrm{b}$, but the slope is not 1 . This means that the machinelearning fit and the observed data distributions differ slightly in their location and scale (Chambers et al., 1983; Fowlkes, 1987). The slope and intercept provide estimates of the scale and location. In our case the left end of the pattern is generally slightly above the $1: 1$ line and the right end of the pattern is slightly below the line indicating that the PDF for the machinelearning fit has slightly shorter tails at each end of the distribution when compared to the PDF of the observations. In most cases the machine-learning approach slightly underestimates the largest $\mathrm{PM}_{2.5}$ abundances, but agrees with in-situ observations to within the estimated uncertainty.

Taylor diagrams - This type of graph, intoduced by Taylor (2001) provides another visual way to compare the machine-learning fit to the hourly average $\mathrm{PM}_{2.5}$ abundance in $\mu \mathrm{g} / \mathrm{m}^{3}$ to the observations (Fig. 5). The Taylor diagram quantifies the similarity between the fit and observations based on the correlation coefficient, the centred root-mean-square (RMS) difference
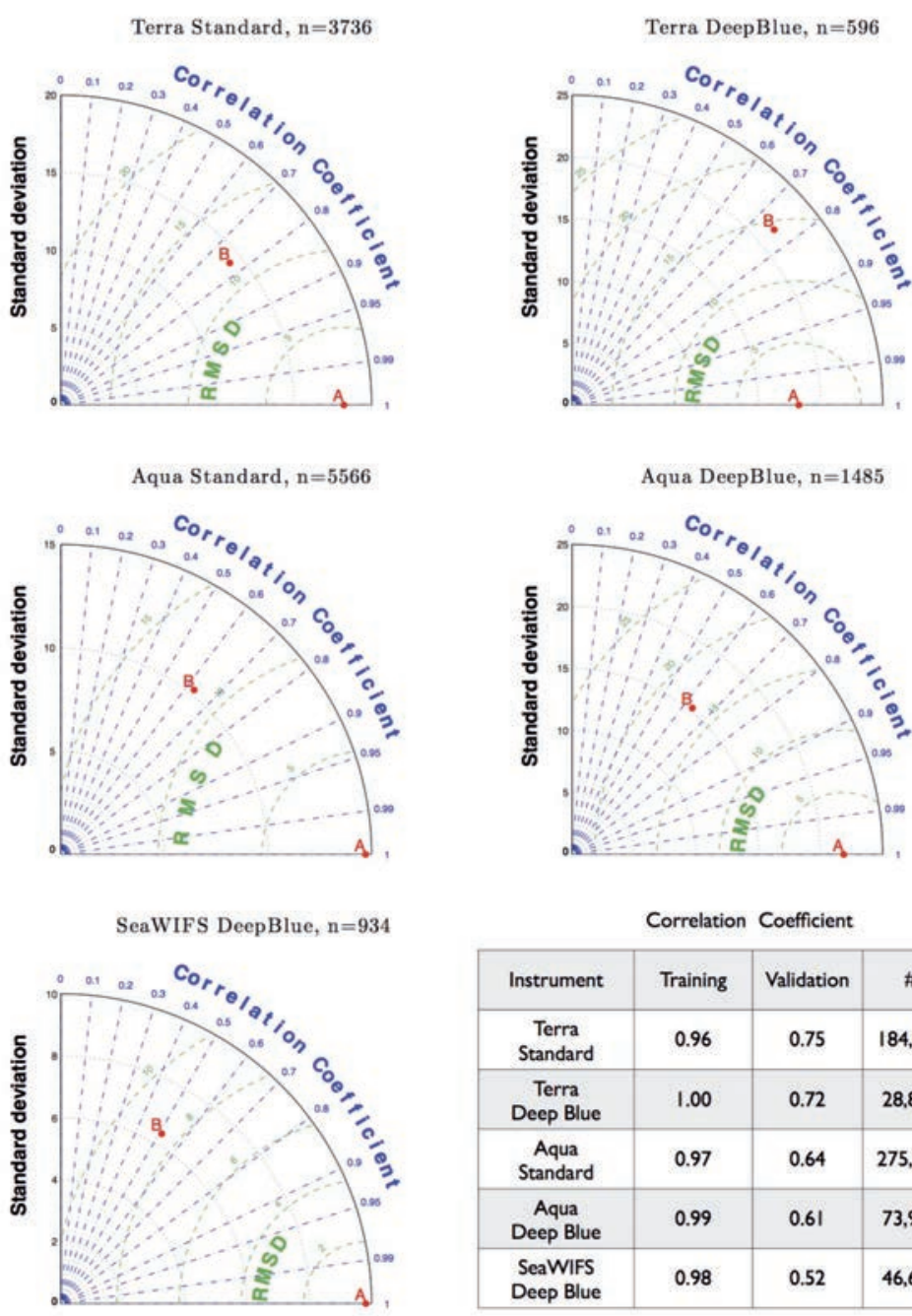

\begin{tabular}{|c|c|c|c|}
\hline \multicolumn{4}{|c}{ Correlation Coefficient } \\
\hline Instrument & Training & Validation & $\#$ \\
\hline $\begin{array}{c}\text { Terra } \\
\text { Standard }\end{array}$ & 0.96 & 0.75 & 184,028 \\
\hline $\begin{array}{c}\text { Terra } \\
\text { Deep Blue }\end{array}$ & 1.00 & 0.72 & 28,820 \\
\hline $\begin{array}{c}\text { Aqua } \\
\text { Standard }\end{array}$ & 0.97 & 0.64 & 275,245 \\
\hline $\begin{array}{c}\text { Aqua } \\
\text { Deep Blue }\end{array}$ & 0.99 & 0.61 & 73,983 \\
\hline $\begin{array}{c}\text { SeaWiFS } \\
\text { Deep Blue }\end{array}$ & 0.98 & 0.52 & 46,605 \\
\hline
\end{tabular}

Fig. 5. Taylor diagrams quantify the similarity between the fit and observations and the amplitude of their variations, i.e. the similarity between fit and observations based on the correlation coefficient and the centred RMS difference on the one hand, and the amplitude of their variations using the standard deviation on the other. In each case, the observations are denoted by point A on the $\mathrm{x}$-axis. The green contours around A show the centred RMS differences between fit and observations. The radial distance of a point from the origin is proportional to the amplitude of variation quantified by the standard deviation. Points lying on a radial arc, at the same distance from the origin as point $\mathrm{A}$, have the same standard deviation indicating that the simulated variations have the correct amplitude. 
between the fit and observations and the amplitude of their variations using the standard deviation. In each case the observations are denoted by point $\mathrm{A}$ on the $\mathrm{x}$ axis. The green contours shown around A indicate the centred RMS differences between the fit and observations. The radial distance of a point from the origin is proportional to the amplitude of variation quantified by the standard deviation. Points lying on a radial arc the same distance from the origin as point $\mathrm{A}$ have the same standard deviation as the observations indicating that the simulated variations have the correct amplitude. We can see from Fig. 5 that all the machine-learning fits are of reasonable quality, but those using the Deep Blue data simulate the amplitude of variation seen in the observations better than the standard algorithm.

Ensemble errors - Fig. 6 shows the ensemble training errors in $\mu \mathrm{g} / \mathrm{m}^{3}$ for our $\mathrm{PM}_{2.5}$ abundance estimates. The blue lines show the RMS error evaluated for the training dataset and the red lines show the RMS error for the independent validation dataset. The ensemble training errors depend on how many members are in the machine-learning ensemble. There is a decrease in the error between one and six ensemble members that then plateaus with little benefit in having more than fifteen learners. In this study we have used an ensemble size of twelve.

\section{Multi-annual estimate of $P M_{2.5}$ abundance}

A useful validation of the new $\mathrm{PM}_{2.5}$ data product is to survey the key features of the global $\mathrm{PM}_{2.5}$ distribution and see if they capture, what we expect to find, and what has been reported in the literature. The upper panel of Fig. 7 shows the global average of the surface $\mathrm{PM}_{2.5}$ abundance estimated using machinelearning of the 5,874 daily estimates from August 1 1997 to August 312013 in $\mu \mathrm{g} / \mathrm{m}^{3}$. Overlaid as colour- filled circles are the observations for those locations, for which we have both a machine-learning estimate of the surface $\mathrm{PM}_{2.5}$ abundance and an observation for at least one third of the 5,874 days between August 1, 1997 to August 31, 2013. The agreement between the machine-learning estimate and the in-situ observations is well within the estimated uncertainty shown in the lower panel.

\section{Results}

Machine-learning estimates works best with a high volume of good quality training data (i.e. USA, Europe, Israel, Tasmania, a few sites in Chile and some parts of Asia). As can be seen in Fig. 2, the volume of training data has increased with time. The most significant recent data sources have come from a network of Chinese monitors. Asia is probably the most challenging region to accurately estimate $\mathrm{PM}_{2.5}$ abundance. This is due to both the magnitude of the sources and the large spatial and temporal gradients. The estimates in Asia were dramatically improved by the inclusion of the Asian monitoring sites in our training datasets. The second most challenging regions are Africa and South America due to the paucity of observations and a range of large $\mathrm{PM}_{2.5}$ sources. The inclusion of Israeli, South African, Mexican, Chilean and Brazilian monitoring sites in our training datasets did improve the quality for Africa and South America. The third most challenging regions are Australia and New Zealand. The inclusion of the excellent Tasmania network as well as Australian and New Zealand monitoring sites dramatically improved the quality of our $\mathrm{PM}_{2.5}$ abundance estimates in these countries. However, more $\mathrm{PM}_{2.5}$ monitoring stations are needed in the Arabian peninsula, Africa, the Philippines, Indonesia, India and South America.
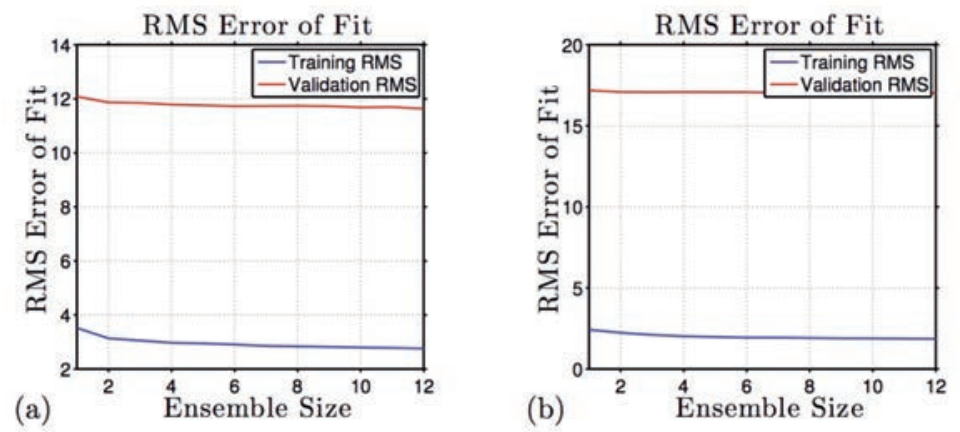

Fig. 6. Ensemble training errors in $\mu \mathrm{g} / \mathrm{m}^{3}$ for the Aqua Standard machine-learning $\mathrm{PM}_{2.5}$ estimates (a), and the Aqua Deep Blue machine-learning $\mathrm{PM}_{2.5}$ estimates (b). The blue lines show the RMS error evaluated for the training dataset, and the red lines the RMS error for the independent validation dataset. 

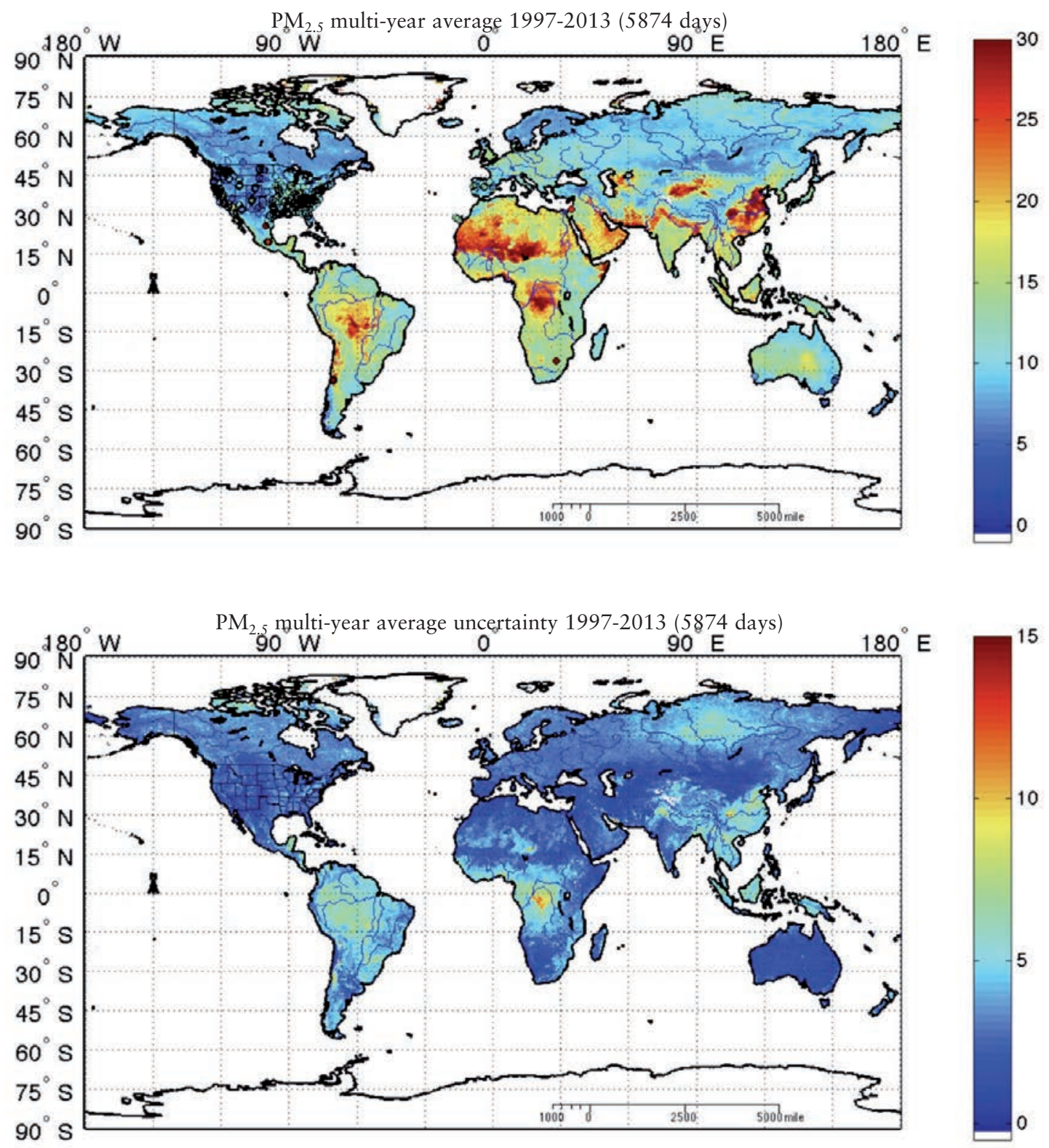

Fig. 7. The global average of the surface $\mathrm{PM}_{2.5}$ abundance of the 5,874 daily estimates from August 11997 to August 312013 (upper panel) with the estimated uncertainty (lower panel). The surface load of $\mathrm{PM}_{2.5}$ is expressed in $\mu \mathrm{g} / \mathrm{m}^{3}$ with the observations for those locations, for which we have both a machine-learning estimate of the surface $\mathrm{PM}_{2.5}$ abundance and an observation for at least one third of the 5,874, overlaid as colour-filled circles. The agreement between the machine-learning estimate and the in situ observations is well within the estimated uncertainty shown in the lower panel.

It is worth noting that the uncertainty estimate is provided by our machine-learning approach. Just as we learnt the behaviour of the $\mathrm{PM}_{2.5}$ abundance as a function of the 30 plus parameters obtained from satellites, meteorological analyses and population density estimates, we also learnt a second quantity, namely the uncertainty of our $\mathrm{PM}_{2.5}$ abundance as a function of the same 30 plus parameters. So for Saharan Africa and the Middle East, where there are few $\mathrm{PM}_{2.5}$ monitors (apart from in Israel), the uncertainty is based objectively on how well the machine-learning algorithm was able to estimate the $\mathrm{PM}_{2.5}$ abundance for that part of the parameter space defined by the 30 plus parameters covering AOD, temperature, humidity etc. Sporadic wildfires and biomass burning are a major source of $\mathrm{PM}_{2.5}$ in places such as sub-Saharan Africa, Amazonia, parts of Mexico, western USA, etc. These sporadic sources are not so pronounced in Fig. 7 as it represents such a long-term average as 5,874 daily estimates from August 11997 to August 31 2013. However, the burning in 
some regions is so persistent that it is evident even in the long-term average, e.g. in the Democratic Republic of Congo (marked $\mathrm{M}$ in Fig. 8).

\section{Key features by region}

The Americas - In Fig. 8a we see that the eastern half has a higher average abundance of $\mathrm{PM}_{2.5}$ than the western half of the USA with the exception of California
(Herner et al., 2005). This is consistent with the overlaid EPA observations shown as colour-filled circles. The fill for the observations uses the same colour scale as the machine-learning background estimates. There are persistently high levels of $\mathrm{PM}_{2.5}$ in Mexico's dusty and desolate Baja California Sur. The particularly high values are in Muleg Municipality close to Guerrero Negro (A). The Sonoran Desert (B), a region characterised by high average $\mathrm{PM}_{2.5}$ abundance and

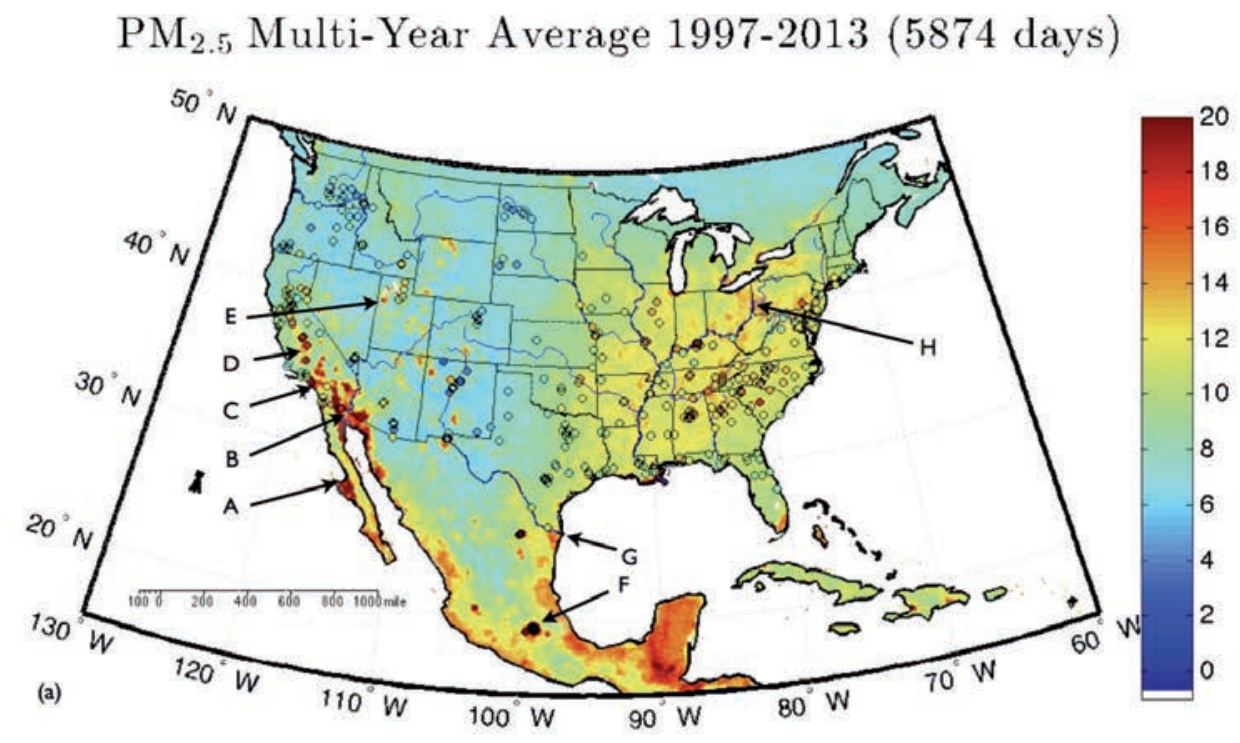

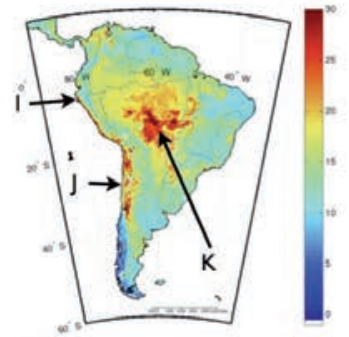

(b)

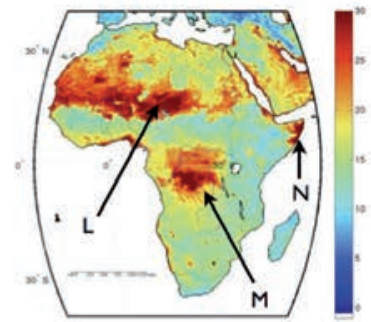

(c)

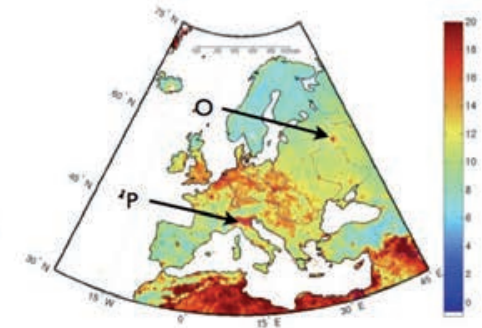

(d)

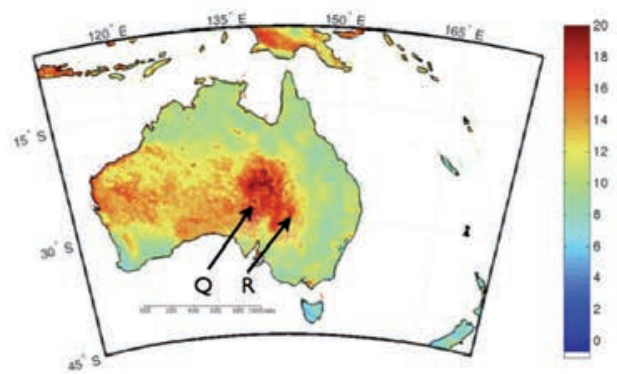

(e)

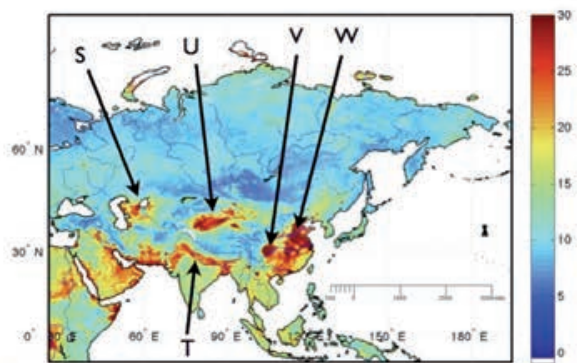

(f)

Fig. 8. The average of the surface $\mathrm{PM}_{2.5}$ abundance of the 5,874 daily estimates from August 1,1997 to August 312013 in $\mu \mathrm{g} / \mathrm{m}^{3}$ for the world's inhabited continents. Particularly high levels of $\mathrm{PM}_{2.5}$ are found in Muleg Municipality close to Guerrero Negro (A); the Sonoran Desert (B); Los Angeles (C); Central Valley in California (D); Great Salt Lake Desert, Utah (E); Mexico City (F); the Chihuahuan and the Big Bend deserts (G); Ohio River Valley $(\mathrm{H})$;. Piura Desert (I); coast from Andean Altiplano Basin to Neuquen Basin $(\mathrm{J})$; Amazon area, Bolivia $(\mathrm{K})$; Bodelle depression in Chad (L); south of Congo River $(\mathrm{M})$; coastal Somalia $(\mathrm{N})$; Moscow $(\mathrm{O})$; Po Valley (P); Lake Eyre (Q); Strzelecki Desert (R); Aral Sea (S) Ganges Valley (T); Taklimakan Desert (U); Sichuan Basin (V); and the region from Beijing to Guangxi in China (W). 
American dust storms (Haboobs) (Idso et al., 1972; Vasquez et al., 1998; Wilt et al., 1998), straddles the region close to the Mexico, Arizona and California borders (Brazel and Nickling, 1978; Holcombe et al., 1997). It covers an area of $311,000 \mathrm{~km}^{2}$ and is one of the hottest and dustiest parts of North America. This is clearly evident in the high 16-year average $\mathrm{PM}_{2.5}$ abundance in this region.

The persistently high $\mathrm{PM}_{2.5}$ abundance associated with Los Angeles (C) is visible. As observed by van Donkelaar et al. (2006), the regions of high population density coincide with the region of high particulate abundance. California's heavily agricultural Central Valley (D) has a high $\mathrm{PM}_{2.5}$ load (note the good agreement of our estimates with the 16 year average observations). The EPA has designated Central Valley as a non-attainment area for the 24hour $\mathrm{PM}_{2.5}$ National Ambient Air Quality Standards (NAAQS). The high $\mathrm{PM}_{2.5}$ abundance associated with the Great Salt Lake Desert in northern Utah (E) close to the Nevada border stands out. There is a nearby measurement "supersite" at Salt Lake City (Long et al., 2003) recording a particulate abundances consistent with our estimates.

Mexico City is known for its high levels of particulates and is clearly visible as a localised hotspot $(\mathrm{F})$. Close to the Mexico/Texas border we see the elevated $\mathrm{PM}_{2.5}$ abundance associated with the Chihuahuan Desert and the Big Bend Desert $(G)$. Dust storms in this area often impact El Paso in Texas and Ciudad Juarez in Mexico (Rivera et al., 2010, 2009; Baddock et al., 2011). The Ohio River Valley (H) encompasses several states and is home to numerous coal-fired power plants, chemical plants and industrial facilities, leading to high levels of ambient particulates (Khosah et al., 2000; Anderson et al., 2004; Yatavelli et al., 2006; Kim et al., 2007). The Ohio River Valley has a higher average abundance of $\mathrm{PM}_{2.5}$ than the rest of the East Coast. Our analysis agrees closely with the insitu observations reported by (Yatavelli et al., 2006) for the Athens "supersite". The Piura Desert in northern Peru (I) on the coast and western slopes of the Andes is a region of high particulate abundances. The region in South America $(\mathrm{J})$ stretching from the high Andean semi-arid Altiplano basin in the North, coming down through the Salar de Uyuni Desert (the world's largest salt flats), passing by Santiago in Chile (Koutrakis et al., 2005) and San Miguel de Tucumn, San Juan and Mendoza in Argentina and down to the Neuquen Basin in the South is characterised by a high abundance of particles from a combination of dust, salt and pollution. The southern Amazon in Bolivia and the surrounding region $(\mathrm{K})$ has a lot of burning leading to persistently high particulate abundances.

Africa - The Bodelle depression (L) is Chad's lowest point on the Sahara's southern edge that supplies the Amazon forest with the majority of its mineral dust (Washington and Todd, 2005; Koren et al., 2006; Washington et al., 2006a,b; Todd et al., 2007; Bouet et al., 2012). The high abundance of $\mathrm{PM}_{2.5}$ over the Bodelle is clearly visible. Typically, there are dust storms originating from the Bodelle depression around 100 days a year. Washington and Todd (2005) examined the dynamical controls of the Bodelle lowlevel jet features. The major source of the world's Aeolian dust is the Sahara (Goudie and Middleton, 2001; Middleton and Goudie, 2001). The low, flat area that is Western Sahara is some of the most inhospitable and arid land on earth and a substantial dust source, clearly visible in the high abundance of $\mathrm{PM}_{2.5}$. Burning in the Democratic Republic of Congo (M) leads to high levels of particulates. Much of coastal Somalia $(\mathrm{N})$ is desert characterised by high levels of particulates.

Europe - An example of a local pollution hotspot in Europe is Moscow $(\mathrm{O})$. Otherwise, the Italian Po Valley $(\mathrm{P})$ has some of the highest average fine particle abundance in Europe with industrial emissions coupled with persistent fog leading to smog (Zappoli et al., 1999; Schaap et al., 2002; Putaud et al., 2004; Crosier et al., 2007).

Australia - Lake Eyre (Q) is Australia's largest lake and lowest point, but it usually only fills with water after heavy rains that typically occur only every three years; otherwise it consists of a salt crust. When the lake does fill, the depth is usually up to $1.5 \mathrm{~m}$; once in a decade it will fill up to $4 \mathrm{~m}$, after which the level falls by around $30 \mathrm{~cm}$ a month. When Lake Eyre has dried out, it is Australia's largest dust source, while the $\mathrm{PM}_{2.5}$ abundance there and in its vicinity is lower than usual during the periods when it is filled with water. Just east of the Lake Eyre Basin is the Strzelecki Desert (R), another major Australian dust source. The arid region just south of the Hamersley Range in Western Australia, i.e. the Gibson Desert, Great Victoria Desert and MacDonnell Ranges, are also dusty environments with elevated average abundances of $\mathrm{PM}_{2.5}$.

Asia - Asia has some of the highest particulate abundances anywhere on Earth. The Aral Sea (S) lying across the border of Kazakhstan and Uzbekistan is heavily polluted with major public health problems. The Ganges Valley $(\mathrm{T})$ is home to 100 million people and is highly polluted. The cold Taklimakan Desert of northwest China (U) has an 
area of $337,000 \mathrm{~km}^{2}$ and is a major source of $\mathrm{PM}_{2.5}$, and so is the situatuion in the Sichhuan the Sichuan $\operatorname{Basin}(\mathrm{V})$ and in the western China in the region from Beijing in the North down to Guangxi in the South (W).

\section{Discussion}

A $\mathrm{PM}_{2.5}$ data product useful for human health studies needs to resolve both spatial and temporal variability. Figs. 3 and 4 show that our machine-learning approach well reproduces the shape of the probability distributions of the globally observed $\mathrm{PM}_{2.5}$ abundance. Figs. 7 and 8 show that it also reproduces the global average spatial distributions well.

A strength of this study is the daily global coverage from 1997 to the present. However, as a consequence of having a wide array of point sources, the $\mathrm{PM}_{2.5}$ abundance can contain high spatial variability on small scales. The spatial resolution of our study is 10 x $10 \mathrm{~km}$ (approximately $0.1^{\circ} \times 0.1^{\circ}$ ) determined by the spatial resolution of the MODIS collection-5 aerosol products. Spatial variability on scales smaller than $10 \mathrm{~km}$ is present. However, they are unresolved in our data product and there are also data gaps due to both cloud coverage and the difficulty that the standard MODIS retrieval algorithm has with retrievals over bright surfaces. MODIS collection- 6 is about to be released and will help address several of these issues. This collection will have $3-\mathrm{km}$ resolution and greater Deep Blue data coverage. Collection- 6 will include various refinements, such as extended coverage to vegetated and bright land surfaces, improved cloud screening, surface reflectance and aerosol microphysical models. In addition, any satellite instrument has a finite life and both MODIS satellites (Terra and Aqua) are aging. We hope data continuity will be provided by the recently launched Visible Infrared Imaging Radiometer Suite (VIIRS) on the Suomi National Polar-orbiting Partnership weather satellite. When data quality from VIIRS becomes acceptable those data can also be used. Although to our knowledge, we have used more training data than any other studies of $\mathrm{PM}_{2.5}$ estimation, there are yet certain parts of the world from where we are still collecting such data. This lack of uniformity in training data may cause some inconsistency in data product quality. However, as we make progress in acquiring more ground $\mathrm{PM}_{2.5}$ data from different parts of the world with missing information, the quality of our dataset will be improved for those parts of the world as well.

\section{Conclusions}

A new approach to use ground-based observations of PM together with a suite of remote sensing and meteorological data products training a machinelearning algorithm to estimate the daily distributions of $\mathrm{PM}_{2.5}$ has been demonstrated. This new $\mathrm{PM}_{2.5}$ daily global data product reproduces global observations and spans an unprecedented 16 years from 1997 to the present. The correlation coefficient for each of the five training datasets is 0.96 or greater and the correlation coefficient for each of the independent validation datasets is 0.52 or greater. The quality varies slightly with satellite, with the best fits obtained from Terra data, followed by Aqua and SeaWIFS. In all cases the shape of $\mathrm{PM}_{2.5}$ data product reproduces the observations between the $25^{\text {th }}$ and $75^{\text {th }}$ quantiles. The machine-learning $\mathrm{PM}_{2.5}$ data product is useful for human health studies as it resolves both spatial and temporal variability.

\section{Acknowledgments}

It is a pleasure to acknowledge the Institute for Integrative Health, the University of Texas at Dallas, DoD TATRC for Award W81XWH-11-2-0165, Grant Number R21ES019713 from the National Institute of Environmental Health Sciences and NASA for research funding through the award NNX11AL18G. The content is solely the responsibility of the authors and does not necessarily represent the official views of the funding agencies. It is a pleasure to acknowledge the environment agencies of Albania, Australia, Austria, Azores Islands, Belarus, Belgium, Brazil, Canada, Canary Islands, Chile, China, Croatia, Cyprus, Czech Republic, Denmark, Estonia, Finland, France, Germany, Greece, Hong Kong, Hungary, Iceland, Iceland, India, Ireland, Israel, Italy, Japan, Latvia, Lithuania, Madeira Islands, Malaysia, Mexico, Mongolia, New Zealand, Netherlands, Norway, Peru, Poland, Portugal, Russia, Singapore, Slovakia, South Africa, South Korea, Spain, Sweden, Taiwan, Thailand, United Kingdom, United States and Vietnam for the use of their $\mathrm{PM}_{2.5}$ observations.

\section{References}

Andersen ZJ, 2012. Health effects of long-term exposure to air pollution: an overview of major respiratory and cardiovascular diseases and diabetes. Chem Ind Chem Eng Q 18, 617-622. Andersen ZJ, Raaschou-Nielsen O, Ketzel M, Jensen SS, Hvidberg M, Loft S, Tjonneland A, Overvad K, Sorensen M, 2012. Diabetes incidence and long-term exposure to air pollution a cohort study. Diabetes Care 35, 92-98.

Anderson HR, Butland BK, van Donkelaar A, Brauer M, 
Strachan DP, Clayton T, van Dingenen R, Amann M, Brunekreef B, Cohen A, et al., 2012. Satellite-based estimates of ambient air pollution and global variations in childhood asthma prevalence. Environ Health Perspect 120, 1333-1339. Anderson RR, Martello DV, White CM, Crist KC, John K, Modey WK, Eatough DJ, 2004. The regional nature of $\mathrm{PM}_{2.5}$ episodes in the upper Ohio River Valley. J Air Waste Manag Assoc 54, 971-984.

Araujo JA, 2011. Particulate air pollution, systemic oxidative stress, inflammation, and atherosclerosis. Air Qual Atmos Health 4, 79-93.

Araujo JA, Barajas B, Kleinman M, Wang X, Bennett BJ, Gong KW, Navab M, Harkema J, Sioutas C, Lusis AJ, Nel AE, 2008. Ambient particulate pollutants in the ultrafine range promote early atherosclerosis and systemic oxidative stress. Circ Res 102, 589-596.

Ayala A, Brauer M, Mauderly JL, Samet JM, 2012. Air pollutants and sources associated with health effects. Air Qual Atmos Health 5, 151-167.

Baccarelli A, Barretta F, Dou C, Zhang X, McCracken JP, Diaz A, Bertazzi PA, Schwartz J, Wang S, Hou L, 2011. Effects of particulate air pollution on blood pressure in a highly exposed population in Beijing, China: a repeated-measure study. Environ Health 10, 108.

Baccarelli A, Tarantini L, Bonzini M, Apostoli P, Pegoraro V, Bollati V, Marinelli B, Cantone L, Rizzo G, Hou L, et al., 2008. Effects of particulate matter on genomic DNA methylation content and inos promoter methylation. Epidemiology 19, S259-S260.

Baccarelli A, Wright RO, Bollati V, Tarantini L, Litonjua AA, Suh HH, Zanobetti A, Sparrow D, Vokonas PS, Schwartz J, 2009. Rapid DNA methylation changes after exposure to traffic particles. Am J Respir Crit Care Med 179, 572-578.

Baddock MC, Gill TE, Bullard JE, Dominguez Acosta M, Rivera NIR, 2011. Geomorphology of the Chihuahuan Desert based on potential dust emissions. J Maps 2011, 249-259.

Ballester F, Medina S, Boldo E, Goodman P, Neuberger M, Iniguez C, Kunzli N, Apheis N, 2008. Reducing ambient levels of fine particulates could substantially improve health: a mortality impact assessment for 26 European cities. J Epidemiol Community Health 62, 98-105.

Block ML, Calderon-Garciduenas L, 2009. Air pollution: mechanisms of neuroinflammation and CNS disease. Trends Neurosci 32, 506-516.

Boldo E, Linares C, Lumbreras J, Borge R, Narros A, GarciaPerez J, Fernandez-Navarro P, Perez-Gomez B, Aragones N, Ramis R, et al., 2011. Health impact assessment of a reduction in ambient $\mathrm{PM}_{2.5}$ levels in Spain. Environ Int 37, 342-348.

Boldo E, Medina S, LeTertre A, Hurley F, Muecke HG, Ballester F, Aguilera I, Eilstein D, Apheis, G, 2006. Apheis: health impact assessment of long-term exposure to $\mathrm{PM}_{2.5}$ in 23 European cities. Eur J Epidemiol 21, 449-458.
Bouet C, Cautenet G, Bergametti G, Marticorena B, Todd MC, Washington R, 2012. Sensitivity of desert dust emissions to model horizontal grid spacing during the bodele dust experiment 2005. Atmos Environ 50, 377-380.

Brauer M, Amann M, Burnett RT, Cohen A, Dentener F, Ezzati M, Henderson SB, Krzyzanowski M, Martin RV, Van Dingenen R, vet al., 2012. Exposure assessment for estimation of the global burden of disease attributable to outdoor air pollution. Environ Sci Technol 46, 652-660.

Brazel AJ, Nickling WG, 1987. Dust storms and their relation to moisture in the Sonoran-Mojave desert region of the Southwestern United States. J Environ Manage 24, 279-291.

Brook RD, 2008. Cardiovascular effects of air pollution. Clin Sci (Lond) 115, 175-187.

Brook RD, Bard RL, Kaplan MJ, Yalavarthi S, Morishita M, Dvonch JT, Wang L, Yang H-Y, Spino C, Mukherjee B, et al., 2013. The effect of acute exposure to coarse particulate matter air pollution in a rural location on circulating endothelial progenitor cells: results from a randomized controlled study. Inhal Toxicol 25, 587-592.

Brook RD, Rajagopalan S, 2009. Particulate matter, air pollution, and blood pressure. J Am Soc Hypertens 3, 332-350.

Brook RD, Rajagopalan S, 2012. Can what you breathe trigger a stroke within hours? Arch Intern Med 172, 235-236.

Brook RD, Rajagopalan S, Pope C, Arden I, Brook JR, Bhatnagar A, Diez-Roux AV, Holguin F, Hong Y, Luepker RV, et al., 2010a. Particulate matter air pollution and cardiovascular disease an update to the scientific statement from the American Heart Association. Circulation 121, 2331-2378.

Brook RD, Xu X, Bard RL, Dvonch JT, Morishita M, Kaciroti N, Sun Q, Harkema J, Rajagopalan S, 2013. Reduced metabolic insulin sensitivity following sub-acute exposures to low levels of ambient fine particulate matter air pollution. Sci Total Environ 448, 66-71.

Byun HM, Panni T, Motta V, Hou L, Nordio F, Apostoli P, Bertazzi PA, Baccarelli AA, 2013. Effects of airborne pollutants on mitochondrial dna methylation. Part Fibre Toxicol 10,18 .

Cesaroni G, Forastiere F, Stafoggia M, Andersen ZJ, Badaloni C, Beelen R, Caracciolo B, de Faire U, Erbel R, Eriksen KT, et al., 2014. Long term exposure to ambient air pollution and incidence of acute coronary events: prospective cohort study and meta-analysis in 11 European cohorts from the ESCAPE Project. BMJ 348, 12.

Chambers JM, Cleveland WS, Kleiner B, Tukey PA, 1983. Graphical methods for data analysis, Wadsworth International Group, Belmont, Calif.

Chen JC, Schwartz J, 2009. Neurobehavioral effects of ambient air pollution on cognitive performance in us adults. Neurotoxicology 30, 231-239.

Choi YS, Ho CH, Chen D, Noh YH, Song, CK, 2008. Spectral analysis of weekly variation in $\mathrm{PM}_{10}$ mass concentration and 
meteorological conditions over China. Atmos Environ 42, 655-666.

Crosier J, Allan JD, Coe H, Bower KN, Formenti P, Williams PI, 2007. Chemical composition of summertime aerosol in the Po Valley (Italy), Northern Adriatic and Black Sea. Q J Roy Meteor Soc 133, 61-75.

Crouse DL, Peters PA, van Donkelaar A, Goldberg MS, Villeneuve PJ, Brion O, Khan S, Atari DO, Jerrett M, Pope C, et al., 2012. Risk of non accidental and cardiovascular mortality in relation to long-term exposure to low concentrations of fine particulate matter: A Canadian national-level cohort study. Environ Health Perspect 120, 708-714.

Dadvand P, Parker J, Bell ML, Bonzini M, Brauer M, Darrow LA, Gehring U, Glinianaia SV, Gouveia N, Ha EH, et al., 2013. Maternal exposure to particulate air pollution and term birth weight: A multi-country evaluation of effect and heterogeneity. Environ Health Perspect 121, 367-373.

Dales R, Burnett RT, Smith-Doiron M, Stieb DM, Brook JR, 2004. Air pollution and sudden infant death syndrome. Pediatrics 113, E628-E631.

De Prins S, Koppen G, Jacobs G, Dons E, Van de Mieroop E, Nelen V, Fierens F, Panis LI, De Boever P, Cox B, et al., 2013. Influence of ambient air pollution on global DNA methylation in healthy adults: a seasonal follow-up. Environ Int 59, 418 424.

Dockery DW, Pope CA, Xu XP, Spengler JD, Ware JH, Fay ME, Ferris BG, Speizer FE, 1993. An association between air-pollution and mortality in 6 United States cities. N Engl J Med 329, 1753-1759.

Engel-Cox JA, Hoff RM, Haymet ADJ, 2004. Recommendations on the use of satellite remote-sensing data for urban air quality. J Air Waste Manag Assoc 54, 13601371.

Engel-Cox JA, Hoff RM, Rogers R, Dimmick F, Rush AC, Szykman JJ, Al-Saadi J, Chu DA, Zell ER, 2006. Integrating LIDAR and satellite optical depth with ambient monitoring for 3-dimensional particulate characterization. Atmos Environ 40, 8056-8067.

Engel-Cox JA, Holloman CH, Coutant BW, Hoff RM, 2004. Qualitative and quantitative evaluation of MODIS satellite sensor data for regional and urban scale air quality. Atmos Environ 38, 2495-2509.

Engel-Cox J, Oanh NTK, van Donkelaar A, Martin RV, Zell E, 2013. Toward the next generation of air quality monitoring: particulate matter. Atmos Environ 80, 584-590.

Farhat SCL, Silva CA, Orione MAM, Campos LMA, Sallum AME, Braga ALF, 2011. Air pollution in autoimmune rheumatic diseases: a review. Autoimmun Rev 11, 14-21.

Fowlkes EB, 1987. A folio of distributions: a collection of theoretical quantile-quantile plots. New York: Marcel Dekker, 540 pp.

Franklin M, Zeka A, Schwartz J, 2007. Association between
$\mathrm{PM}_{2.5}$ and all-cause and specific-cause mortality in 27 US communities. J Expo Sci Environ Epidemiol 17, 279-287.

Ginoux P, Torres O, 2003. Empirical TOMS index for dust aerosol: applications to model validation and source characterization. J Geophys Res Atmos 108, 4534.

Glinianaia SV, Rankin J, Bell R, Pless-Mulloli T, Howel D, 2004. Does particulate air pollution contribute to infant death? A systematic review. Environ Health Perspect 112, 1365-1370.

Goudie AS, Middleton NJ, 2001. Saharan dust storms: nature and consequences. Earth-Sci Rev 56, 179-204.

Herner JD, Aw J, Gao O, Chang DP, Kleeman MJ, 2005. Size and composition distribution of airborne particulate matter in northern California: I-particulate mass, carbon, and water-soluble ions. J Air Waste Manage Assoc 55, 30-51.

Hoff RM, Christopher SA, 2009. Remote sensing of particulate pollution from space: have we reached the promised land? J Air Waste Manage Assoc 59, 642-644.

Hoffmann B, Moebus S, Dragano N, Stang A, Moehlenkamp S, Schmermund A, Memmesheimer M, Broecker-Preuss M, Mann K, Erbel R, et al., 2009. Chronic residential exposure to particulate matter air pollution and systemic inflammatory markers. Environ Health Perspect 117, 1302-1308.

Holcombe TL, Ley T, Gillette DA, 1997. Effects of prior precipitation and source area characteristics on threshold wind velocities for blowing dust episodes, Sonoran Desert 1948-78. J Appl Meteorol 36, 1160-1175.

Hou L, Wang S, Dou C, Zhang X, Yu Y, Zheng Y, Avula U, Hoxha M, Diaz A, McCracken J, et al., 2012. Air pollution exposure and telomere length in highly exposed subjects in Beijing, China: a repeated-measure study. Environ Int 48, 7177.

Hou L, Zhang X, Dioni L, Barretta F, Dou C, Zheng Y, Hoxha M, Bertazzi PA, Schwartz J, Wu S, et al., 2013. Inhalable particulate matter and mitochondrial DNA copy number in highly exposed individuals in Beijing, China: a repeated-measure study. Part Fibre Toxicol 10.

Hou L, Zhu ZZ, Zhang X, Nordio F, Bonzini M, Schwartz J, Hoxha M, Dioni L, Marinelli B, Pegoraro V, et al., 2010. Airborne particulate matter and mitochondrial damage: a cross-sectional study. Environ Health 9.

Hsu NC, Tsay SC, King MD, Herman JR, 2004. Aerosol properties over bright-reflecting source regions. IEEE Trans Geosci Remote Sens 42, 557-569.

Hsu NC, Tsay SC, King MD, Herman JR, 2006. Deep blue retrievals of Asian aerosol properties during ACE-Asia. IEEE Trans Geosci Remote Sens 44, 3180-3195.

Hyer EJ, Reid JS, Zhang J, 2011. An over-land aerosol optical depth data set for data assimilation by filtering, correction, and aggregation of MODIS collection 5 optical depth retrievals. Atmos Meas Tech 4, 379-408.

Hystad P, Demers PA, Johnson KC, Brook J, van Donkelaar A, 
Lamsal L, Martin R, Brauer M, 2012. Spatiotemporal air pollution exposure assessment for a Canadian population-based lung cancer case-control study. Environ Health 11, 22.

Hystad P, Setton E, Cervantes A, Poplawski K, Deschenes S, Brauer M, van Donkelaar A, Lamsal L, Martin R, Jerrett M, et al., 2011. Creating national air pollution models for population exposure assessment in Canada. Environ Health Perspect 119, 1123-1129.

Hystad P, Setton E, Cervantes A, Poplawski K, Deschenes S, Tomlins M, Martin R, Van Donkelaar A, 2009. Feasibility of a Canadian land use regression model for $\mathrm{PM}_{2.5}$ exposure assessment. Epidemiology 20, S191.

Idso SB, Ingram RS, Pritchar JM, 1972. An American haboob. B Am Meteorol Soc 53, 930-935.

Ji H, Hershey GKK, 2012. Genetic and epigenetic influence on the response to environmental particulate matter. Am J Clin Exp Immunol 129, 33-41.

Kaufman J, 2011. An update on the multiethnic study of atherosclerosis and air pollution. Epidemiology 22, S226-S227.

Khosah RP, McManus TJ, Feeley TJ, 2000. Ambient fine particulate $\left(\mathrm{PM}_{2.5}\right)$ monitoring research for the upper Ohio River Valley project. Abstr Pap Am Chem Soc 219, 45-49.

Kim M, Deshpande SR, Crist KC, 2007. Source apportionment of fine particulate matter $\left(\mathrm{PM}_{2.5}\right)$ at a rural Ohio River Valley site. Atmos Environ 41, 9231-9243.

Koren I, Kaufman YJ, Washington R, Todd MC, Rudich Y, Martins JV, Rosenfeld D, 2006. The bodele depression: a single spot in the Sahara that provides most of the mineral dust to the Amazon forest. Environ Res Lett 1, 4345-4372.

Koutrakis P, Sax SN, Sarnat JA, Coull B, Demokritou P, Oyola P, Garcia J, Gramsch E, 2005. Analysis of $\mathrm{PM}_{10}, \mathrm{PM}_{2.5}$, and $\mathrm{PM}_{2.5}-10$ concentrations in Santiago, Chile, from 1989 to 2001. J Air Waste Manag Assoc 55, 342-351.

Kreyling WG, Semmler-Behnke M, Moller W, 2006. Ultrafine particle-lung interactions: does size matter? J Aerosol Med 19, 74-83.

Kumar N, Chu AD, Foster AD, Peters T, Willis R, 2011. Satellite remote sensing for developing time and space resolved estimates of ambient particulate in Cleveland, OH. Aerosol Sci Technol 45, 1090-1108.

Lary DJ, Remer LA, MacNeill D, Roscoe B, Paradise S, 2009. Machine learning and bias correction of MODIS aerosol optical depth. IEEE Trans Geosci Remote Sens 6, 694-698.

Lary DJ, Woolf S, Faruque F, LePage J, 2014. Holistics 3.0 for Health. ISPRS Int J Geo-Inf 3, 1023-1038.

Lee HJ, Liu Y, Coull BA, Schwartz J, Koutrakis P, 2011a. A novel calibration approach of MODIS AOD data to predict $\mathrm{PM}_{2.5}$ concentrations. Atmos Chem Phys 11, 7991-8002.

Lee HJ, Liu Y, Coull B, Schwartz, Koutrakis P, 2011b. PM 2.5 prediction modeling using MODIS AOD and its implications for health effect studies. Epidemiology 22, S215.

Lipfert FW, Zhang J, Wyzga RE, 2000. Infant mortality and air pollution: a comprehensive analysis of US data for 1990. J Air Waste Manag Assoc 50, 1350-1366.

Liu Y, Chen D, Kahn RA, He K, 2009a. Review of the applications of multiangle imaging spectroradiometer to air quality research. Sci China Ser D Earth Sci 52, 132-144.

Liu Y, Franklin M, Kahn R, Koutrakis P, 2007a. Using aerosol optical thickness to predict ground-level $\mathrm{PM}_{2.5}$ concentrations in the St. Louis area: a comparison between MISR and MODIS. Remote Sens Environ 107, 33-44.

Liu Y, He K, Li S, Wang Z, Christiani DC, Koutrakis P, 2012. A statistical model to evaluate the effectiveness of $\mathrm{PM}_{2.5}$ emissions control during the Beijing 2008 olympic games. Environ Int 44, 100-105.

Liu YJ, Harrison RM, 2011. Properties of coarse particles in the atmosphere of the United Kingdom. Atmos Environ 45, 32673276.

Liu Y, Kahn RA, Chaloulakou A, Koutrakis P, 2009b. Analysis of the impact of the forest fires in august 2007 on air quality of Athens using multi-sensor aerosol remote sensing data, meteorology and surface observations. Atmos Environ 43, 3310-3318.

Liu Y, Koutrakis P, Kahn R, 2007b. Estimating fine particulate matter component concentrations and size distributions using satellite-retrieved fractional aerosol optical depth: part 1 method development. J Air Waste Manag Assoc 57, 13511359.

Liu Y, Koutrakis P, Kahn R, Turquety S, Yantosca RM, 2007c. Estimating fine particulate matter component concentrations and size distributions using satellite-retrieved fractional aerosol optical depth: part 2 - a case study. J Air Waste Manag Assoc 57, 1360-1369.

Liu Y, Paciorek CJ, Koutrakis P, 2009. Estimating regional spatial and temporal variability of $\mathrm{PM}_{2.5}$ concentrations using satellite data, meteorology, and land use information. Environ Health Perspect 117, 886-892.

Liu Y, Paciorek C, Koutrakis P, 2008. Estimating daily pm2.5 exposure in Massachusetts with satellite aerosol remote sensing data, meteorological, and land use information. Epidemiology 19, S116.

Liu Y, Park RJ, Jacob DJ, Li QB, Kilaru V, Sarnat, JA, 2004. Mapping annual mean ground-level $\mathrm{PM}_{2.5}$ concentrations using multiangle imaging spectroradiometer aerosol optical thickness over the contiguous United States. J Geophys Res Atmos 109, D22206.

Liu Y, Sarnat JA, Kilaru A, Jacob DJ, Koutrakis P, 2005. Estimating ground-level $\mathrm{PM}_{2.5}$ in the Eastern United States using satellite remote sensing. Environ Sci Technol 39, 32693278.

Long RW, Eatough NL, Mangelson NF, Thompson W, Fiet K, Smith S, Smith R, Eatough DJ, Pope CA, Wilson WE, 2003. The measurement of PM2.5, including semi-volatile components, in the EMPACT program: results from the Salt Lake 
City Study. Atmos Environ 37, 4407-4417.

Lyamani H, Olmo FJ, Alcantara A, Alados-Arboledas L, 2006. Atmospheric aerosols during the 2003 heat wave in southeastern Spain I: spectral optical depth. Atmos Environ 40, 64536464.

Madrigano J, Baccarelli A, Mittleman MA, Wright RO, Sparrow D, Vokonas PS, Tarantini L, Schwartz J, 2011. Prolonged exposure to particulate pollution, genes associated with glutathione pathways, and DNA methylation in a cohort of older men. Environ Health Perspect 119, 977-982.

Maheswaran R, Pearson T, Smeeton NC, Beevers SD, Campbell MJ, Wolfe CD, 2010. Impact of outdoor air pollution on survival after stroke population-based cohort study. Stroke 41, 869-877.

Maheswaran R, Pearson T, Smeeton NC, Beevers SD, Campbell MJ, Wolfe CD, 2012. Outdoor air pollution and incidence of ischemic and hemorrhagic stroke a small-area level ecological study. Stroke 43, 22-27.

Martin RV, 2008. Satellite remote sensing of surface air quality. Atmos Environ 42, 7823-7843.

Melin F, Zibordi G, Carlund T, Holben BN, Stefan S, 2013. Validation of SeaWiFS and MODIS Aqua/Terra aerosol products in coastal regions of European marginal seas. Oceanologia 55, 27-51.

Middleton NJ, Goudie AS, 2001. Saharan dust: sources and trajectories. Trans Inst Br Geogr 26, 165-181.

Natunen A, Arola A, Mielonen T, Huttunen J, Komppula M, Lehtinen KEJ, 2010. A multi-year comparison of $\mathrm{PM}_{2.5}$ and AOD for the Helsinki region. Boreal Environ Res 15, 544-552.

Paciorek CJ, Liu Y, 2009. Limitations of remotely sensed aerosol as a spatial proxy for fine particulate matter. Environ Health Perspect 117, 904-909.

Paciorek CJ, Liu Y, 2012. Assessment and statistical modeling of the relationship between remotely sensed aerosol optical depth and $\mathrm{PM}_{2.5}$ in the Eastern United States. Res Rep Health Eff Inst 167.

Paciorek CJ, Liu Y, Moreno-Macias H, Kondragunta S, 2008. Spatiotemporal associations between GOES aerosol optical depth retrievals and ground-level $\mathrm{PM}_{2.5}$. Environ Sci Technol 42, 5800-5806.

Patel MM, Miller RL, 2009. Rapid DNA Methylation changes after exposure to traffic particles: the issue of spatio-temporal factors. Am J Respir Crit Care Med 180, 1030-1030.

Pearson JF, Bachireddy C, Shyamprasad S, Goldfine AB, Brownstein JS, 2010. Association between fine particulate matter and diabetes prevalence in the US. Diabetes Care 33, 2196-2201.

Pelletier B, Santer R, Vidot J, 2007. Retrieving of particulate matter from optical measurements: a semiparametric approach. J Geophys Res Atmos 112, D06208.

Pope C, Arden I, Brook RD, Burnett RT, Dockery DW, 2011. How is cardiovascular disease mortality risk affected by dura- tion and intensity of fine particulate matter exposure? An integration of the epidemiologic evidence. Air Qual Atmos Health 4, 5-14.

Pope C, Arden I, Burnett RT, Krewski D, Jerrett M, Shi Y, Calle EE, Thun MJ, 2009. Cardiovascular mortality and exposure to airborne fine particulate matter and cigarette smoke shape of the exposure-response relationship. Circulation 120, 941948.

Pope C, Dockery, DW, 2006. Health effects of fine particulate air pollution: lines that connect. J Air Waste Manag Assoc 56, 709-742.

Prospero JM, 2003. Global dust transport over the oceans: the link to climate. Geochim Cosmochim Acta 67, A384-A384.

Putaud JP, Raes F, Van Dingenen R, Bruggemann E, Facchini MC, Decesari S, Fuzzi S, Gehrig R, Huglin C, Laj P, et al., 2004. European aerosol phenomenology-2: Chemical characteristics of particulate matter at kerbside, urban, rural and background sites in Europe. Atmos Environ 38, 2579-2595.

Rajeev K, Parameswaran K, Nair SK, Meenu S, 2008. Observational evidence for the radiative impact of Indonesian smoke in modulating the sea surface temperature of the equatorial Indian Ocean. J Geophys Res Atmos 113, D17201.

Reid JS, Hyer EJ, Johnson RS, Holben BN, Yokelson RJ, Zhang J, Campbell JR, Christopher SA, Girolamo LD, Giglio L, et al., 2013. Observing and understanding the southeast Asian aerosol system by remote sensing: an initial review and analysis for the seven southeast Asian studies (7seas) program. Atmos Res 122, 403-468.

Remer LA, Kleidman RG, Levy RC, Kaufman YJ, Tanre D, Mattoo S, Martins JV, Ichoku C, Koren I, Yu H, et al., 2008. Global aerosol climatology from the MODIS satellite sensors. J Geophys Res Atmos 113, D14S07.

Rienecker MM, Suarez MJ, Gelaro R, Todling R, Bacmeister J, Liu E, Bosilovich MG, Schubert SD, Takacs L, Kim GK, et al., 2011. Merra: nasa's modern-era retrospective analysis for research and applications. J Clim 24, 3624-3648.

Rivera NIR, Gill TE, Bleiweiss MP, Hand JL, 2010. Source characteristics of hazardous Chihuahuan Desert dust outbreaks. Atmos Environ 44, 2457-2468.

Rivera NIR, Gill TE, Gebhart KA, Hand JL, Bleiweiss MP, Fitzgerald RM, 2009. Wind modeling of Chihuahuan Desert dust outbreaks. Atmos Environ 43, 347-354.

Ruckerl R, Schneider A, Breitner S, Cyrys J, Peters A, 2011. Health effects of particulate air pollution: a review of epidemiological evidence. Inhal Toxicol 23, 555-592.

Salam MT, Byun HM, Lurmann F, Breton CV, Wang X, Eckel SP, Gilliland FD, 2012. Genetic and epigenetic variations in inducible nitric oxide synthase promoter, particulate pollution, and exhaled nitric oxide levels in children. J Allergy Clin Immunol 129, 232-239.

Salam MT, Millstein J, Li YF, Lurmann FW, Margolis HG, Gilliland FD, 2005. Birth outcomes and prenatal exposure to 
ozone, carbon monoxide, and particulate matter: results from the children's health study. Environ Health Perspect 113, 1638-1644.

Sayer AM, Hsu NC, Bettenhausen C, Jeong MJ, 2013. Validation and uncertainty estimates for MODIS collection 6 “deep blue" aerosol data. J Geophys Res Atmos 118, 78647872.

Schaap M, Apituley A, Timmermans RMA, Koelemeijer RBA, de Leeuw G, 2009. Exploring the relation between aerosol optical depth and $\mathrm{PM}_{2.5}$ at Cabauw, the Netherlands. Atmos Chem Phy 9, 909-925.

Schaap M, Muller K, ten Brink HM, 2002. Constructing the European aerosol nitrate concentration field from quality analysed data. Atmos Environ 36, 1323-1335.

Shi Y, Zhang J, Reid JS, Hyer EJ, Hsu NC, 2012. Critical evaluation of the MODIS deep blue aerosol optical depth product for data assimilation over North Africa. Atmos Measure Tech Discuss 5, 7815-7865.

Slama R, Darrow L, Parker J, Woodruff TJ, Strickland M, Nieuwenhuijsen M, Glinianaia S, Hoggatt KJ, Kannan S, Hurley F, et al., 2008. Meeting report: atmospheric pollution and human reproduction. Environ Health Perspect 116, 791 798.

Sunderman FW, 2001. Review: nasal toxicity, carcinogenicity, and olfactory uptake of metals. Ann Clin Lab Sci 31, 3-24.

Tarantini L, Bonzini M, Apostoli P, Pegoraro V, Bollati V, Marinelli B, Cantone L, Rizzo G, Hou L, Schwartz J, et al. 2009. Effects of particulate matter on genomic dna methylation content and inos promoter methylation. Environ Health Perspect 117, 217-222.

Taylor K, 2001. Summarizing multiple aspects of model performance in a single diagram. J Geophys Res 106, 7183-7192.

Tian D, Wang Y, Bergin M, Hu Y, Liu Y, Russell AG, 2008. Air quality impacts from prescribed forest fires under different management practices. Environ Sci Technol 42, 2767-2772.

Todd MC, Washington R, Martins JV, Dubovik O, Lizcano G, M'Bainayel S, Engelstaedter S, 2007. Mineral dust emission from the Bodele depression, northern Chad, during Bodex 2005. J Geophys Res Atmos 112, D06207.

van de Kassteele J, Koelemeijer RBA, Dekkers ALM, Schaap M, Homan CD, Stein A, 2006. Statistical mapping of $\mathrm{PM}_{10}$ concentrations over Western Europe using secondary information from dispersion modeling and MODIS satellite observations. Stoch Environ Res Risk Assess 21, 183-194.

van Donkelaar A, Martin RV, Brauer M, Kahn R, Levy R, Verduzco C, Villeneuve PJ, 2010. Global estimates of ambient fine particulate matter concentrations from satellite-based aerosol optical depth: Development and application. Environ Health Perspect 118, 847-855.

van Donkelaar A, Martin RV, Levy RC, da Silva AM, Krzyzanowski M, Chubarova NE, Semutnikova E, Cohen AJ, 2011. Satellite-based estimates of ground-level fine particulate matter during extreme events: a case study of the Moscow fires in 2010. Atmos Environ 45, 6225-6232.

van Donkelaar A, Martin RV, Park RJ, 2006. Estimating ground-level $\mathrm{PM}_{2.5}$ using aerosol optical depth determined from satellite remote sensing. J Geophys Res 111, D21201.

van Donkelaar A, Martin R, Verduzco C, Brauer M, Kahn R, Levy R, Villeneuve P, 2010. A hybrid approach for predicting $\mathrm{PM}_{2.5}$ exposure response. Environ Health Perspect 118, A425. Vasquez HR, Fausett J, Sipple S, Estle WT, Haro JA, Wojcik W, Berkovitz R, Sturm D, Cushmeer N, Jamison A, et al., 1998. A South-Central Arizona Haboob - the 28 July 1994 wind and dust storm. Part 1: event forecastability, $16^{\text {th }}$ conference on weather analysis and forecasting / symposium on the research foci of the U.S. Weather Research Program.

Villeneuve PJ, Goldberg MS, Burnett RT, van Donkelaar A, Chen H, Martin RV, 2011. Associations between cigarette smoking, obesity, sociodemographic characteristics and remote-sensing-derived estimates of ambient $\mathrm{PM}_{2.5}$ : Results from a Canadian population-based survey. Occup Environ Med 68, 920-927.

Wang BL, Li XL, Xu XB, Sun YG, Zhang Q, 2012. Prevalence of and risk factors for subjective symptoms in urban preschool children without a cause identified by the guardian. Arch Environ Occup Health 85, 483-491.

Wang Q, Shao M, Liu Y, William K, Paul G, Li X, Liu Y, Lu S, 2007. Impact of biomass burning on urban air quality estimated by organic tracers: Guangzhou and Beijing as cases. Atmos Environ 41, 8380-8390.

Washington R, Todd MC, 2005. Atmospheric controls on mineral dust emission from the Bodele depression, Chad: The role of the low level jet. Geophys Res Lett 32, L17701.

Washington R, Todd MC, Engelstaedter S, Mbainayel S, Mitchell F, 2006. Dust and the low-level circulation over the Bodele depression, Chad: Observations from Bodex 2005. J Geophys Res Atmos 111, D06207.

Washington R, Todd MC, Lizcano G, Tegen I, Flamant C, Koren I, Ginoux P, Engelstaedter S, Bristow CS, Zender CS, et al., 2006. Links between topography, wind, deflation, lakes and dust: the case of the Bodele depression, Chad. Geophys Res Lett 33, L09401.

Weber SA, Engel-Cox JA, Hoff RM, Prados AI, Zhang H, 2010. An improved method for estimating surface fine particle concentrations using seasonally adjusted satellite aerosol optical depth. J Air Waste Manag Assoc 60, 574-585.

Wilt RE, Breckenridge CA, Davis JT, Franjevic MW, Wojcik W, Cushmeer N, Amer Meteorol SOC, 1998. A South-Central Arizona Haboob - the 28 July 1994 wind and dust storm. Part 2: radar and satellite observations, $16^{\text {th }}$ conference on weather analysis and forecasting / symposium on the research foci of the U.S. Weather Research Program.

Woodruff TJ, Grillo J, Schoendorf KC, 1997. The relationship between selected causes of postneonatal infant mortality and 
particulate air pollution in the United States. Environ Health Perspect 105, 608-612.

Woodruff TJ, Morello-Frosch R, Jesdale B, 2008. Air pollution and preeclampsia among pregnant women in California, 1996-2004. Epidemiology 19, S310-S310.

Woodruff TJ, Parker JD, Schoendorf, KC, 2006. Fine particulate matter $\left(\mathrm{PM}_{2.5}\right)$ air pollution and selected causes of postneonatal infant mortality in California. Environ Health Perspect 114, 786-790.

Yatavelli RLN, Fahrni JK, Kim M, Crist KC, Vickers CD, Winter SE, Connell DP, 2006. Mercury, $\mathrm{PM}_{2.5}$ and gaseous copollutants in the Ohio River Valley Region: Preliminary results from the Athens supersite. Atmos Environ 40, 6650-6665.

Zappoli S, Andracchio A, Fuzzi S, Facchini MC, Gelencser A, Kiss G, Krivacsy Z, Molnar A, Meszaros E, Hansson HC, et al., 1999. Inorganic, organic and macromolecular components of fine aerosol in different areas of Europe in relation to their water solubility. Atmos Environ 33, 2733-2743.

Zeft AS, Prahalad S, Lefevre S, Clifford B, McNally B, Bohnsack JF, Pope CAI, 2009. Juvenile idiopathic arthritis and exposure to fine particulate air pollution. Clin Exp Rheumatol 27, 877884.

Zhang H, Hoff RM, Engel-Cox JA, 2009. The relation between moderate resolution imaging spectroradiometer (MODIS) aerosol optical depth and $\mathrm{PM}_{2.5}$ over the United States: a geographical comparison by US Environmental Protection Agency Regions. J Air Waste Manag Assoc 59, 1358-1369.

Zhang H, Lyapustin A, Wang Y, Kondragunta S, Laszlo I, Ciren P, Hoff RM, 2011. A multi-angle aerosol optical depth retrieval algorithm for geostationary satellite data over the United States. Atmos Chem Phys 11, 11977-11991.

Zhang J, Reid JS, 2009. An analysis of clear sky and contextual biases using an operational over ocean MODIS aerosol product. Geophys Res Lett 36. 